medRxiv preprint doi: https://doi.org/10.1101/2020.10.21.20216986; this version posted March 4, 2021. The copyright holder for this preprint (which was not certified by peer review) is the author/funder, who has granted medRxiv a license to display the preprint in perpetuity.

It is made available under a CC-BY-NC-ND 4.0 International license .

3

\title{
Simulation and prediction of spread of COVID-19 in The Republic of Serbia by SEIRDS model of disease transmission
}

\author{
${ }^{*}$ Slavoljub STANOJEVIC ${ }^{a}$, Mirza PONJAVIC ${ }^{b}$, Slobodan STANOJEVIC ${ }^{c}$, Aleksandar \\ STEVANOVIC ${ }^{d}$, Sonja RADOJICIC ${ }^{e}$
}

\section{${ }^{a}$ Directorate of National Reference Laboratories, Batajnicki drum 10, 11080 Zemun, Serbia}

${ }^{\mathrm{b}}$ International Burch University, Francuske revolucije bb, Ilidza 71210, Sarajevo, Bosnia and Herzegovina, e-mail: mirza.ponjavic@gis.ba

${ }^{\complement}$ Veterinary Scientific Institute of Serbia, Janisa Janulisa 14, 11107 Belgrade, Serbia, e-mail: slobodan.vet@gmail.com

'University of Pittsburgh, Department of Civil and Environmental Engineering, 3700 O'Hara Street, Pittsburgh, PA 15261, USA, e-mail: stevanovic@pitt.edu

${ }^{\text {e} B e l g r a d e ~ U n i v e r s i t y, ~ F a c u l t y ~ o f ~ V e t e r i n a r y ~ M e d i c i n e ~-~ D e p a r t m e n t ~ o f ~ I n f e c t i o u s ~ D i s e a s e s ~ a n d ~}$ Epidemiology, Bulevar Oslobodenja 18, 11000 Belgrade, Serbia, e-mail: sonjar@vet.bg.ac.rs

${ }^{\star}$ Corresponding author: Slavoljub Stanojevic, e mail: slavoljub.stanojevic@minpolj.gov.rs

\section{Abstract}

As a response to the pandemic caused by SARS-Cov-2 virus, on 15 March, 2020, the Republic of Serbia introduced comprehensive anti-epidemic measures to curb COVID-19. After a slowdown in the epidemic, on 6 May, 2020, the regulatory authorities decided to relax the implemented measures. However, the epidemiological situation soon worsened again. As of 7 February, 2021, a total of 406,352 cases of SARSCov-2 infection have been reported in Serbia, 4,112 deaths caused by COVID-19. In order to better understand the epidemic dynamics and predict possible outcomes, we have developed an adaptive mathematical model SEAIHRDS (S-susceptible, E-exposed, A-asymptomatic, I-infected, Hhospitalized, R-recovered, D-dead due to COVID-19 infection, S-susceptible). The model can be used to simulate various scenarios of the implemented intervention measures and calculate possible epidemic outcomes, including the necessary hospital capacities. Considering promising results regarding the 
medRxiv preprint doi: https://doi.org/10.1101/2020.10.21.20216986; this version posted March 4, 2021. The copyright holder for this preprint (which was not certified by peer review) is the author/funder, who has granted medRxiv a license to display the preprint in perpetuity.

It is made available under a CC-BY-NC-ND 4.0 International license.

development of a vaccine against COVID-19, the model is extended to simulate vaccination among different population strata. The findings from various simulation scenarios have shown that, with implementation of strict measures of contact reduction, it is possible to control COVID-19 and reduce number of deaths. The findings also show that limiting effective contacts within the most susceptible population strata merits a special attention. However, the findings also show that the disease has a potential to remain in the population for a long time, likely with a seasonal pattern. If a vaccine, with efficacy equal or higher than $65 \%$, becomes available it could help to significantly slow down or completely stop circulation of the virus in human population.

The effects of vaccination depend primarily on: 1 . Efficacy of available vaccine(s), 2. Prioritization of the population categories for vaccination, and 3. Overall vaccination coverage of the population, assuming that the vaccine(s) develop solid immunity in vaccinated individuals. With expected basic reproduction number of $R_{0}=2.46$ and vaccine efficacy of $68 \%$, an $87 \%$ coverage would be sufficient to stop the virus circulation.

Keywords: COVID-19, SEAIHRDS mathematical model, prediction, vaccination

\section{Introduction}

On 11 March, 2020, the World Health Organization characterised the disease caused by the novel SARS-Cov-2 virus as a pandemic [1]. The Initial epidemic outbreak in China spread outside the Wuhan area, and subsequently on a global scale. On 6 March, 2020, the first case of the novel coronavirus infection was reported in the Republic of Serbia. Taking into consideration the escalation of the disease and limited effects of the initially implemented measures, the state of emergency was declared throughout the country on 15 March, 2020. Comprehensive anti-epidemic measures (e.g. lockdown of entire country) were introduced in the entire country [2].

Due to the absence of specific pharmaceutical intervention, Serbia, like other countries, implemented an anti-epidemic strategy based on physical distancing, school and university closures, reduced number of workers present in the workplaces, closure of places of worship for public religious services, reduced working hours of cafés and restaurants, avoiding mass gatherings, events, sports games, tracing and identification of infected people's contacts, etc. After a slowdown in the epidemic, as 
medRxiv preprint doi: https://doi.org/10.1101/2020.10.21.20216986; this version posted March 4, 2021. The copyright holder for this preprint (which was not certified by peer review) is the author/funder, who has granted medRxiv a license to display the preprint in perpetuity.

It is made available under a CC-BY-NC-ND 4.0 International license.

shown in the relevant officially published data, the regulatory authorities decided to relax the introduced measures on 6 May, 2020. However, the epidemiological situation soon worsened again, resulting in the reinstatement of some measures, as well as the introduction of new measures [2]. Although the return of extensive measures has yielded favourable results, the further development of the epidemic is not clear.

For these reasons, mathematical modelling has a crucial role in understanding the epidemic and predicting possible outcomes. Modelling is a particularly useful tool for devising strategies for combating the epidemic, capacity planning, and selection of efficient measures, especially in the absence of specific pharmaceutical treatments $[3,4,5]$. Mathematical modelling based on differential equations dates back to the first half of $20^{\text {th }}$ century. In 1927, Kermack and McKendrick developed the basic model of disease transmission consisting of three compartments: susceptible (S), infected (I) and removed (R). The model was based on a connected system of nonlinear differential equations as a special case of the general epidemiological model $[6,7]$. Subsequent models, became more complex and adapted to the needs of research [5].

Since the outbreak of COVID-19, many published papers have dealt with the implementation of mathematical modelling and prediction of possible outcomes of COVID-19 epidemics. Most of these research efforts have been based on the implementation of the SIR (susceptible-infected-removed) model. Many of the other models provide a clear picture of dynamics of COVID-19 spreading, including the overloading of the relevant_health systems. For example, Ferguson et al., developed one of the first models for COVID19 simulation, which was, among other things, used to plan the health care resources [8]. Wu et al., developed the SEIR model to examine the dynamics of SARS-Cov-2 transmission from person to person. This model was also used to calculate the basic reproduction number $R_{o}$, which we use in this paper as one of the key parameters [9]. The classical SIR model assumes that there is homogenous mixing of infected and susceptible populations and that the total population is constant and does not change over time. Moreover, according to the classical SIR model, there is a monotonous decline in susceptible population towards zero [10]. However, such assumptions are not objective in the case of COVID-19 spreading and they are the basic problem in the modelling of this pandemic. In reality, the human population fluctuates constantly [11]. In order to account for such fluctuation, and better understand the COVID-19 epidemic in the Republic of Serbia, we have employed mathematical modelling 
medRxiv preprint doi: https://doi.org/10.1101/2020.10.21.20216986; this version posted March 4, 2021. The copyright holder for this preprint (which was not certified by peer review) is the author/funder, who has granted medRxiv a license to display the preprint in perpetuity.

It is made available under a CC-BY-NC-ND 4.0 International license.

of the epidemic using the available data on the characteristics of the disease, such as incubation period, latent period, recovery period, severity of clinical signs, and mortality rate caused by COVID-19.

Unlike the classic SIR model, the SEAIHRDS (S-susceptible, E-exposed, A-asymptomatic, Iinfected, H-hospitalized, R-recovered, D-dead due to COVID-19 infection, S-susceptible) epidemic model, developed for this research, simulates the spreading of COVID-19 in an open population. Taking into account that the population is constantly changing and that various measures are applied for different strata or subgroups of the population (such as preschool children, children attending primary school, high school students, students, employees, the unemployed and retirees), as well as changes in the intensity of applied measures, we have proposed the use of a model that takes these circumstances into account. Based on input disease parameters taken from scientific literature and specific data related to Serbia, this model simulates daily disease occurrence, including the number of hospitalized patients and cases which require intensive care. The model also predicts the expected number of deaths, as well as hospital capacities necessary to accommodate the patients. It provides a possibility to simulate different scenarios of disease control and intervention measures. Considering the expectations of successful development of the vaccine against COVID-19 in the near future, we added an option to model vaccination of different strata of the population as a set of disease control strategies.

\section{Methodology}

This section presents the research methodology and the proposed model, which were used to predict the further dynamics of the epidemic in Serbia. We also presented the data that were used to model the epidemic, a simulated strategy to combat COVID-19, and a sensitivity analysis.

\subsection{SEAIHRDS mathematical model}

Classical SEIRDS model divides the population into compartments, i.e. groups, and follows the disease dynamics at all times. The population is divided into the following compartments: the portion of the population susceptible to the infection is denoted by $S$, those latently infected with SARSCov-2 (exposed to) are denoted by E, the infected individuals who are able to spread the disease are denoted by I, the ones recovered from the infection are denoted by $R$, and those who died due to disease with $D$. 
medRxiv preprint doi: https://doi.org/10.1101/2020.10.21.20216986; this version posted March 4, 2021. The copyright holder for this preprint (which was not certified by peer review) is the author/funder, who has granted medRxiv a license to display the preprint in perpetuity.

It is made available under a CC-BY-NC-ND 4.0 International license .

113 Assuming that individuals mix homogenously, the force of infection $\lambda$ (the rate at which susceptible

114 persons are infected) is related to per capita contact rate $\beta$. Also, the risk of infection is closely related to

115 the number of infectious individuals in the population $I_{t}$. It depends on the number of infectious individuals

$116\left(\mathrm{I}_{t}\right)$ and how frequently they make contacts with other persons. In a situation of homogenous mixing

117 among the population, the force of infection $\lambda$ can be express as follows:

$118 \lambda(t)=\beta I(t)$

119 The change of rates in every compartment per unit time in SEIRDS model is presented in the following 120 series of differential equations:

$121 S_{t+1}=b N_{t}-\beta S_{t} I_{t}-m S_{t}+\omega R_{t}$

$122 E_{t+1}=\beta S_{t} I_{t}-f E-m E_{t}$

$123 \quad I_{t+1}=f E_{t}-(r+m) I_{t}-\delta I_{t}$

$124 \quad R_{t+1}=r I_{t}-(m+\omega) R_{t}$

$125 \quad D_{t+1}=\delta I_{t}$

126 where $f$ is rate of onset of infectiousness expressed as the reciprocal of the latent infection period, $r$ is

127 the rate at which infectious individuals are recovered, $\delta$ is the rate at which infectious individuals die from 128 COVID-19 infection and $\omega$ is rate of waning of immunity. The total population at any particular interval of 129 time $t$ is:

$N_{t}=S_{t}+E+I_{t}+R_{t}+D_{t}+b N_{t-1}-m S_{t-1}$

131 where parameters $b$ and $m$ are per capita daily birth rate and death rate unrelated to COVID-19.

However, considering that implemented anti-epidemic measures against COVID-19 do not have an identical impact on the population's age subgroups and that COVID-19 pathogenesis varies in different 134 age subgroups, we propose the use of multi-compartment version of standard SEIRDS model. The model, named SEAIHRDS, monitors the dynamics of following compartments: susceptible individuals $(S)$,

136 latently infected with SARSCov-2 $(E)$ (exposed to/presymptomatic), asymptomatic infectious individuals

$137(A)$, infectious individuals with symptoms/clinically ill $(I)$, hospitalized patients $(H)$, recovered individuals

$138(R)$, and those who died due to disease $(D)$. In this model the susceptible population was further stratified 139 within the compartment S according to age and occupations. Grouping into various strata was done 140 according to the real age structure of the Republic of Serbia population as follows: pre-school children 
medRxiv preprint doi: https://doi.org/10.1101/2020.10.21.20216986; this version posted March 4, 2021. The copyright holder for this preprint (which was not certified by peer review) is the author/funder, who has granted medRxiv a license to display the preprint in perpetuity.

It is made available under a CC-BY-NC-ND 4.0 International license.

$141\left(S_{p s}\right)$, elementary school children $\left(S_{e s}\right)$, high school children $\left(S_{h s}\right)$, college students $\left(S_{c s}\right)$, unemployed 142 population $\left(S_{\text {ua }}\right)$, employed population $\left(S_{\text {ea }}\right)$, and elderly/retired $\left(S_{r}\right)$ (Table 1$)$. To simulate the epidemic 143 progression through different population strata-subgroups, we used appropriate, stratum-specific, model 144 parameters and factors of effective contact reduction (anti-epidemic intervention measures - $\rho$ ), which were adapted to the relevant population groups: lockdown of the entire country, closures of pre-school, 146 school and college sessions closures, reduced number of workers allowed in the workplaces, work from 147 home, restrictions of mobility of elderly people, etc. During the simulation, we monitored the effects of various levels of contact reduction, ranging from $20 \%$ to $75 \%$, taking into account the realistic possibilities of maintaining a minimum work process, functioning of the society and feasibility of such measures.

the same for all population strata, homogeneous mixing can be expected only within same population stratum. The rate of effective contacts $\beta$, after the application of intervention measures, is no longer identical at the level of all strata of the population. Effective contacts are limited by the intensity and types of measures applied and are identical only when it comes to individuals within the same population strata. Furthermore, persons in different population strata become infected at different rates depending on how frequently they interact with other persons in their own subgroup and other subgroups. If we assume that 157 force of infection differs between different strata of population, the equation for the force of infection would

where $\lambda_{i}(t)$ is force of infection in the $i^{\text {th }}$ population strata, $\beta_{i j}$ is the rate at which susceptible persons in the $i^{\text {th }}$ population strata and infectious persons in $j^{\text {th }}$ population strata come into effective contact per unit of 161 time, and $I_{j}(t)$ is the number of infectious persons in $j^{\text {th }}$ population strata. Also, in this model the number of 162 recovered and dead is conditioned with different ages and genders.

163 Now our model will be expressed as follows:

$164 \quad \frac{d S_{i}(t)}{d t}=b N(t)-\sum_{j=1}^{n} \beta_{i j} I_{j}(t) S_{i}(t)-\sum_{j=1}^{n} \beta_{i j} \eta A_{j}(t) S_{i}(t)+\omega R_{i}(t)-m S_{i}(t)$

165

$\frac{d E_{i}(t)}{d t}=\sum_{j=1}^{n} \beta_{i j} I_{j}(t) S_{i}(t)+\sum_{j=1}^{n} \beta_{i j} \eta A_{j}(t) S_{i}(t)-(m+f) E_{i}(t)$

166

$\frac{d A_{i}(t)}{d t}=f \alpha E_{i}(t)-(\gamma+m) A_{i}(t)$

167

$\frac{d I_{i}(t)}{d t}=f(1-\alpha) E_{i}(t)-\sum_{j=1}^{n} \sigma_{i j} I_{j}(t)-(r+m) I_{i}(t)$ 
168

169

170

171

172

173

174

175

176

177

178

180

181

182

183

$\frac{d H_{i}(t)}{d t}=\sum_{j=1}^{n} \sigma_{i j} I_{j}(t)-\sum_{j=1}^{n} \delta_{i j} H_{i}(t)-(\varepsilon+m) H_{i}(t)$

$\frac{d R_{i}(t)}{d t}=\sum_{j=1}^{n} r_{i j} I_{j}(t)+\sum_{j=1}^{n} \gamma_{i j} A_{j}(t)+\varepsilon H_{i}(t)-(m+\omega) R_{i}(t)$

$\frac{d D_{i}(t)}{d t}=\sum_{j=1}^{n} \delta_{i j} I_{i}(t)$

where $\alpha$ is the proportion of asymptomatic cases, $\eta$ accounts for the relative infectiousness of asymptomatic carriers (in comparison to symptomatic carriers), $r$ is the rate at which infectious individuals whit symptoms are recovered, $\gamma$ is the rate at which asymptomatic infectious individuals are recovered, $\sigma$ is rate at which infectious individuals are hospitalized, $\varepsilon$ is the rate at which hospitalized patients are recovered, $\delta$ is the rate at which infected individuals die from COVID-19 infection and $\omega$ is rate of waning of immunity (Supplementary material).

\subsection{Determining the herd immunity threshold and control of COVID-19 by vaccination policy}

Considering the undergoing worldwide efforts to develop a vaccine against COVID-19 and promising results, we extended the model to simulate and analysed the effects of a hypothetical vaccination on the epidemic dynamics, and to estimate the extent of coverage of vaccination which can interrupt the chain of infection. The control of COVID-19 by vaccination means targeting the entire susceptible population with mass vaccination until critical herd immunity achieved. In such situation there is a "race" between the exponential growth of epidemic and mass vaccination. The level of herd immunity threshold (HIT) can be calculated by the following formula: $H I T=1-1 / R_{o}=\left(R_{o}-1\right) / R_{o}$ and the critical vaccination coverage required to achieve herd immunity can be obtained by multiplying herd immunity threshold with reciprocal value of vaccine efficacy, $v_{e}$ :

$$
V_{c}=\frac{1}{v_{e}}\left(1-\frac{1}{R_{o}}\right)
$$

Most people infected with SARS-CoV-2 develop an immune response followed by the development of specific antibodies between 10 and 21 days after getting infected [12]. Specific IgM and $\lg \mathrm{g}$ antibodies against SARS-CoV-2 develop 6 to 15 days after the onset of the disease [13-17]. According to some studies, the presence of antibodies has been confirmed in less than $40 \%$ of the patients within 1 week after the onset of the disease, whereas percentage reaches $100 \%$ of subjects 15 days after the onset of disease [18]. Although duration of the immune response against CVOVID 19 is still 
medRxiv preprint doi: https://doi.org/10.1101/2020.10.21.20216986; this version posted March 4, 2021. The copyright holder for this preprint (which was not certified by peer review) is the author/funder, who has granted medRxiv a license to display the preprint in perpetuity.

It is made available under a CC-BY-NC-ND 4.0 International license.

195

196

197

198

199

200

201

202

203

204

205

206

207

208

209

210

211

212

213

214

215

216

217

218

219

220

$\frac{d V_{i}(t)}{d t}=v_{e} S_{i}(t)-m V_{i}-\omega V_{i}$

221 The compartment $\mathrm{S}(\mathrm{t})$ is slightly modified as follows:

222 rate in this compartment per unit time is as follows: unknown, comparing with other coronaviruses, where immunity wane within 12 to 52 weeks after the first symptoms appear $[19,20]$, while in the case of SARS-CoV-1 infection the presence of IgG antibodies was confirmed in $90 \%$ and $50 \%$ of infected patients, respectively, over two and three years, respectively [29], we assumed that durable immunity against COVID-19 is possible [20, 21]. Immunity to HCoVOC43 and HCoV-HKU1 appears to wane appreciably within 1 year [21, 22], whereas SARS-CoV-1 infection can induce longer-lasting immunity [23]. S. F. Lumley et. in a study conducted on 1,246 persons recovered from COVID-19 found no symptomatic re-infections over 6 months [24].

Based on these findings, and fact that SARS-Cov-2 virus is also beta coronavirus, we assumed that in the event of the development of a successful vaccine, immunity against the SARS-Cov-2 virus could last for a year, as well as after recovery after a natural infection. In a study conducted to determine the dynamics of SARS-Cov-2 transmission in the post pandemic period, Kissler et al. applied a similar approach in defining the possible length of the immunity period [20].

For the purpose of modelling a control strategy based on vaccination, additional compartment to the model was added denoted with $\mathrm{V}(\mathrm{t})$, in which there are vaccinated persons who have successfully developed protective immunity after vaccination. The vaccination parameter, $u$, is the daily rate of vaccination of susceptible population and it represents the proportion of susceptible population immunized per unite time. The critical daily rate of vaccination, $\square_{c}$, is $\square_{c}=(b+\omega)\left(R_{o}-1\right)$, required to interrupt the infection [5]. The basic reproduction number under the vaccination is $R_{o p}=(1-p) R_{0}$. The proportion of effectively protected persons, $p$, is conditioned by parameter the vaccine efficacy, $v_{e}$. This parameter represents a proportion of person who successfully developed protective immunity after vaccination, whereas total number of actively protected individuals in time $t$ is $V(t)=$ number of vaccinated $x \quad V_{e}$ [5]. In this compartment the daily rate of waning of immunity at which immunity of vaccinated population fades out is $\omega$, and it is reciprocal to the period of lasting of immunity. Vaccinated persons, after losing their immunity, become sensitive again and removed to the compartment $\mathrm{S}$. The change of

$\frac{d S_{i}(t)}{d t}=b N(t)-\sum_{j=1}^{n} \beta_{i j} I_{j}(t) S_{i}(t)+\omega R_{-} i(t)-m S_{i}(t)-v_{e} S_{i}(t)+\omega V_{i}$ 
medRxiv preprint doi: https://doi.org/10.1101/2020.10.21.20216986; this version posted March 4, 2021. The copyright holder for this preprint (which was not certified by peer review) is the author/funder, who has granted medRxiv a license to display the preprint in perpetuity.

It is made available under a CC-BY-NC-ND 4.0 International license .

223 The other of compartments of SERIDS model remain unchanged.

\subsection{Model parametrisation}

In proposed model, $\beta$ is per capita effective contact rate at which specific persons come into

227 effective contact per unit of time. An effective contact is defined as a contact sufficient to cause disease

228 transmission $[10,24,26]$. We calculated the parameter $\beta$ by using the formula:

$229 \beta=\mathrm{R}_{\mathrm{o}} / \mathrm{NT}_{\mathrm{R}}$

where $R_{0}$ is a basic reproduction number of the disease, i.e. the average number of newly infected people with COVID-19 (secondary infection cases), infected by one infectious individual in a totally susceptible population, $N$ is total population, and $T_{R}$ is the average duration of infectious period $[10,25,26]$. The $R$ values of 2.46 and 3.1 are adopted from the relevant literature. The $R_{0}$ values were based on the data obtained during the initial phase of the epidemic in Italy [27]. Since the implemented measures and disease transmission were simulated through various population strata, we corrected the $\beta$ parameter with a relevant, stratum-specific contact reduction factor $\rho_{i}$. In this way, we obtained the per capita contact rate specific for each separate stratum based on following formula

The values of the $\rho_{i}$ factor in different population strata ranged from 0.25 to 0.75 (effective contact reduction ranged from $25 \%$ to $75 \%)$.

Parameters such as daily birth and death rates were calculated based on the data published by 242 the Office of Statistics of the Republic of Serbia, and data published by the World Bank regarding the life expectancy in the Republic of Serbia [28, 29]. The latter study reported that the life expectancy in Serbia was 79.06 years in 2017 [29]. By using this figure, we expressed the daily death rate as a value reciprocal

245 to life expectancy $m=0.000036$. We calculated the daily per capita birth rate of $b=0.000025$ based on 246 the figure of 9.2 births in the Republic of Serbia per 1000 people in a year. These estimates were needed 247 to realistically simulate fluctuations of the total population. To simplify the calculations, we assumed that 248 the general morality rate $m$ is applicable for all population strata. 
medRxiv preprint doi: https://doi.org/10.1101/2020.10.21.20216986; this version posted March 4, 2021. The copyright holder for this preprint (which was not certified by peer review) is the author/funder, who has granted medRxiv a license to display the preprint in perpetuity.

It is made available under a CC-BY-NC-ND 4.0 International license.

The infectivity rate, i.e. the rate of transfer from compartment $E$ to I, was derived as a value reciprocal to the COVID-19's average latent period. The data on the average duration of latent infection

$251\left(f^{-1}\right)$ and the average period during which an infected person is shading the SARS-Cov-2 virus $\left(T_{R}\right)$ were 252 adopted from the relevant literature as $f^{-1}=3.5$ days $[30,31]$ and $T_{R}=9.3$ days, respectively [30]. Also 253 the data on the percentage of hospitalized patients and those whose therapy requires intensive care, 254 used for prediction of required hospital capacities, as shown in Table 1, were taken from literature [30, 8].

Parameters such as $\delta$ and $r$ are related to the infectious fatality rate (IFR) for COVID-19 and average times taken from onset of symptoms to death $\left(T_{D}\right)$ or recovery $\left(T_{R}\right)$. These parameters were 257 calculated using the following formulas:

$258 \delta=I F R_{\text {stratum }} / T_{D}$ and

$r=\left(1-I F R_{\text {stratum }}\right) / T_{R}$

The IFRs, shown in Table 2, were taken from literature and compared with local IFR value which was calculated based on officially registered deaths published by the health system of the Republic of Serbia [2]. The Calculation of local IFR is presented in section 2.4. Population data, (e.g. total population, age structure, and stratification) are presented in Tables 1 and 2. A summary of all model parameters is given in Table 3.

\subsection{Setting disease control scenarios}

Five different scenarios were developed for simulating the COVID-19 epidemic control based on non-pharmaceutical interventions. SC1 implies a base-case scenario where the epidemic spreads in susceptible population without any anti-epidemic measures being implemented. In the other scenarios, the extent of contacts was reduced, for each population stratum separately, according to objective

271 possibilities and measures which were implemented during the actual epidemic in the Republic of Serbia.

272 Scenarios are presented in Table 4.

The timing of the simulation of anti-epidemic measures, i.e. the reduction of individual contacts

274 corresponds to the actual date when the implementation of measures in the real epidemic in Serbia 275 began (March 15, 2020). Considering that it is not realistic to expect the desired level of reduction of physical contacts to be achieved in one day, in each scenario, a period of gradual introduction of 
medRxiv preprint doi: https://doi.org/10.1101/2020.10.21.20216986; this version posted March 4, 2021. The copyright holder for this preprint (which was not certified by peer review) is the author/funder, who has granted medRxiv a license to display the preprint in perpetuity.

It is made available under a CC-BY-NC-ND 4.0 International license .

measures was simulated (lag period of 7 days). Since each individual scenario was simulated at $R_{0}$ of 2.46 and 3.10, different contact reduction rates were applied accordingly.

Additional four scenarios of control of COVID-19 were simulated based on vaccination policy. We assumed that vaccine efficacy was $50 \%, 68 \%, 80 \%$, and $85 \%$. The initial conditions assumed that all other anti-epidemic measures are excluded from the model and replaced with mass vaccination. Indicators of epidemic dynamics were monitored, such as: $\mathrm{Cl}$, hospitalized patients, patient in intensive care units and deaths.

\subsection{Model sensitivity analysis and calibration}

Considering the world experience with detection of COVID-19 cases, as well as the unreliable data on COVID-19 infections which are currently available worldwide, model calibration is very challenging, and can result in obtaining inaccurate values for the parameters [40]. This is especially due to the facts that a significant percentage of the infected individuals do not exhibit any symptoms. The other issue is small percentage of tested population [40].

As part of the national seroepidemiological study, 1,006 subjects were tested in Serbia from May $11^{\text {th }}$ to June $25^{\text {th }}, 2020$, for the purpose of estimating the extent of COVID-19 infection. According to the published data, seroconversion was confirmed in $6,4 \%$ of the subjects. On the other hand, a total of 13,372 cases of the infection were reported, which means that those who were infected constitute around $0.19 \%$ of the overall population. However, it is our opinion that the data on reported deaths caused by COVID-19 infection is more reliable for use in model calibration, e.g. infection fatality rate. Alex et al. reached a similar conclusion when simulating COVID-19 by using the SEIRD model with heterogeneous diffusion [40]. When we compared the data recorded during the beginning of the epidemic in Serbia with the results obtained during the simulation, such as the initial doubling time, the two data series matched well. However, later, the obtained results did not match well the officially registered data on the number of infected, especially after the beginning of the implementation of measures in Serbia. We attribute these differences to the methodology by which official authorities register cases of infection, and collect the data. 
medRxiv preprint doi: https://doi.org/10.1101/2020.10.21.20216986; this version posted March 4, 2021. The copyright holder for this preprint (which was not certified by peer review) is the author/funder, who has granted medRxiv a license to display the preprint in perpetuity.

It is made available under a CC-BY-NC-ND 4.0 International license .

The parameter that determines the number of deaths is the IFR. It is the number of persons who die of the COVID-19 among all infected individuals regardless of whether the infected show symptoms of the disease or not. As with many diseases, IFR is not always equivalent to the number of reported deaths caused by COVID-19. This is because a significant number of deaths, although caused by COVID-19, will not be recognized as deaths caused by COVID-19 [41]. Also, there are many asymptomatic cases of infection which are never detected [42, 43, 44, 45].

However, according to new findings, the overall estimate of the proportion of people who become infected with SARS-CoV-2 and remain asymptomatic throughout infection was $20 \%$ (95\% confidence interval) with a prediction interval of $3 \%-67 \%$ in 79 studies that addressed this question [46, 47]. Michael A. Johansson et al. reported that $30 \%$ of individuals with infection never develop symptoms and are $75 \%$ as infectious as those who do develop symptoms, and concluded that persons with infection who never develop symptoms may account for approximately $24 \%$ of all transmission [39].

Due the fact that there is a lag in time between when people are infected and when they die, patients who die on any given day were infected much earlier, and thus the denominator of the mortality rate should be the total number of patients infected at the same time as those who died [41]. David et al. estimated mortality rate by dividing of deaths on a given date by the total number of persons confirmed as COVID 19 cases 14 days before [29,41]. It is based on the assumption that maximum incubation period is 14 days [34]. However, if we take into account that the number of registered cases of COVID-19 infection is usually significantly lower than the actual number, assuming that the data on deaths are accurate, the real IFR value is significantly lower than the calculated value [40]. If we apply this to the situation in Serbia, the daily value of IFR on July $10^{\text {th }}, 2020$, when the largest number of deaths was registered in one day, was $9.33 \%$, considering that 18 deaths were registered on July $10^{\text {th }}$ and 14 days earlier 193 confirmed cases of COVID-19 infection. The raw values of IFR for the period between March $6^{\text {th }}$ and August $10^{\text {th }}$ were as follows: median of IFR $=2.11 \%$, and average value of IFR $=7.15 \%$ bounded in interval $4.17 \%-10.13 \%$. When we compared these values with those published by the WHO, CDC and other authors $[43,44,48]$ we concluded that they differ significantly. Considering these findings, the IFR values adopted in the model (for various population groups and genders) were primarily taken from the literature, with a remark that the selection of IFR values was based on preliminary comparison of the 
medRxiv preprint doi: https://doi.org/10.1101/2020.10.21.20216986; this version posted March 4, 2021. The copyright holder for this preprint (which was not certified by peer review) is the author/funder, who has granted medRxiv a license to display the preprint in perpetuity.

It is made available under a CC-BY-NC-ND 4.0 International license.

overall Serbian IFR with similar IFRs found in the literature, taking into account the registered deaths and most probable number of infected individuals [33]. To make this possible, the first step was to correct the local raw IFR value mentioned above. Based on real data we first calculated the population at risk of dying from COVID-19 infection for each individual day since the outbreak, ending on August $10^{\text {th }}, 2020$. The number at risk on a given day should correspond to the number of deaths from COVID-19 infection, considering the lag period from infection to death. For this calculation, we used the data on the number of deaths $D_{t}$ in Serbia registered on daily bases [2]. We hypothesized that the distribution of time periods $t_{n}$ from the moment of COVID19 infection to death follows the lognormal distribution defined by the parameters $m=26.8$ and $\sigma=12.4$ days $[48,49]$.

Based on the formula: $I_{r(t)}=\sum_{j=1}^{n} I_{(t-n)} * m_{(t-n)}$ by reverse, we calculated the population at risk of dying from COVID-19 infection for each individual day, where $m_{t}$ is the probability that the time between infection and death is $t$ days and follows the lognormal distribution $(m=26.8, \sigma=12.4)[48,49]$. After that, the daily IFR values were calculated according to the formula IFR $R_{(t)}=D_{t} / I_{r(t)}[50]$. Based on IFR values calculated in this way, we made descriptive statistics and obtained the mean value of IFR $=0.70 \%$, bounded in the interval $0.46-0.94 \%$ and a median of $0.19 \%$. It is important to note here that this value corresponds with the COVID-19 IFR values found in Eastern European countries and Spain [50, 33]. Taking these findings into account, we decided to take the IFR values specific to certain population strata recorded in Spain as the most appropriate for our case [33]. The adopted IFR values are listed in Table 3. In this section, we used sensitivity analysis to estimate the amount of change on outcomes when varying the input values used in the model. Sensitivity analysis is one of the methods most frequently used for the evaluation of disease spread models [51, 52]. A sensitivity analysis is carried out to characterise the impact of uncertainty of input parameters on model outputs. Sensitivity analysis consists of assessing the impact that changes in input parameters have on model outcomes. We evaluate two aspects of the model: the global behavior of the model when perturbing a group of key parameters together, and the impact of changes when perturbing the key parameters used in the model individually.

The model sensitivity analysis was conducted by changing the most sensitive model parameters: $R_{0}, \beta, f-1, r, b, m, \gamma, \mathcal{E}, \eta, \omega, \bar{\tau}_{d}$. The values of these parameters were increased by $5 \%, 10 \%$ and $25 \%$ relative to the base scenario and changes in output indicators were observed. 
medRxiv preprint doi: https://doi.org/10.1101/2020.10.21.20216986; this version posted March 4, 2021. The copyright holder for this preprint (which was not certified by peer review) is the author/funder, who has granted medRxiv a license to display the preprint in perpetuity.

It is made available under a CC-BY-NC-ND 4.0 International license .

Finaly, validation of the model was performed by comparing the historical data of the real epidemic in Serbia with the data obtained with the SEAIHRDS model. For validation purposes, the current epidemic of COVID-19 was simulated, along with actual anti-epidemic measures. Taking into account the risks described above related to the accuracy of historical data from the COVID-19 epidemic in Serbia and significantly higher confidence in the accuracy of data related to the number of deaths from COVIDA19 compared to data on the number of infected, for the purpose of model validation, only data on the cumulative number of deaths were used. The reason for this assumption is that there is still uncertainty about the proportion of the infected population that is not reported due to a mild form of the disease or the patients are asymptomatic.

In statistical analysis the coefficient of determination, $R^{2}$, was used to check goodness of fit of SEAIHRD model with COVID-19 data recorded during the real epidemic. The regression coefficient compares predicted values $(\mathrm{y})$ against actual data $(\mathrm{x})$. To address model uncertainties, bias, mean

372 absolute error (MAE), mean square error (MSE), the root mean square error (RMSE), maximum deviation 373 (MaxDev) and normalized root mean square error (NRMSE) were also estimated (Supplementary 374 material).

\section{Results}

\subsection{Predicting the number of sick, hospitalized patients and deaths caused by COVID-19 in the} absence of any intervention measures

After the simulation, the model predicted that with $R_{0}=2.46$, and without the implementation of any anti-epidemic measures, the initial doubling time of the infection could be five days. The epidemic wave could peak 219 days after the outbreak, and it could yield 99,819 infected individuals in a day. Afterwards, the infection rate could decline for 215 days, eventually reaching the daily incidence of 492 newly infected, after which the next epidemic wave could start. The second wave could peak 706 days

384 after the onset of epidemic and yielding 25,232 infected individuals in a day. The third epidemic wave could peak 429 days later, with 13,709 infected individuals in a day. The true cumulative incidence in the 
medRxiv preprint doi: https://doi.org/10.1101/2020.10.21.20216986; this version posted March 4, 2021. The copyright holder for this preprint (which was not certified by peer review) is the author/funder, who has granted medRxiv a license to display the preprint in perpetuity.

It is made available under a CC-BY-NC-ND 4.0 International license.

cumulative incidence could be $4,360,401$ infected. A total of 20,894 patients could die due to COVID-19 consequences.

With $R_{0}=3.1$, the following results were obtained: the initial doubling time of the infection was five days, true cumulative incidence 7,133,221, apparent cumulative incidence 4,993,254, and the total deaths of 23,951 . Fig. 1, panels a) and b) show daily variations in the number of susceptible, latently infected, infected and recovered patients, at basic reproduction numbers of $R_{0}=2.46$ and $R_{0}=3$, respectively. Panels $\mathrm{c}$ ) and d) of the same figure show daily fluctuations in susceptible, recovered and net reproduction rates $R_{n}$ for $R_{0}=2.46$ and $R_{0}=3$, respectively. Panels e) and f) of Fig. 1 show daily variations in $R_{n}$, true and apparent disease incidences at basic reproduction numbers of $R_{0}=2.46$ and $R_{0}=3$. The shaded area corresponds to the period when the daily number of new COVID-19 infected individuals increasing, and therefore all of the following hold: $R_{n}>1$, proportion susceptible $>1 / R_{0}$ and the proportion of population that is recovered (immune) is below the herd immunity threshold. Fig. 2 panels a) and b) show a prediction of necessary hospital capacities. Panels c) and d) of Fig. 2 show predicted numbers of sick and dead due to COVID-19 at $R_{0}=2.46$ and $R_{0}=3$ and age structure of hospitalized patients and deaths.

\subsection{Predicting the number of sick, hospitalized patients and deaths caused by COVID-19 in the conditions of application of restrictive anti-epidemic measures}

When the spread of COVID-19 epidemic through totally susceptible population in the Republic of Serbia is simulated, under an assumption of only incidental movement among the population, basic reproduction number of $R_{0}=2.46$, and with lock-down of entire country, a significant slowdown of the epidemic was observed. Initial infection doubling time was 6 days. The peak of the epidemic wave could occur 702 days after the epidemic onset, when there could be 2,848 infected in one day. In the first year of the epidemic 308,581 people could be infected and 1,031 people could die.

When the basic reproductive number was increased to $R_{0}=3.1$, and for certain segments of the population the contact reduction factor $\rho_{i}$ increased compared to the values from the scenario with $\mathrm{R}_{0}=$ 2.46 (reduction of contacts in public places and contacts of persons over 65 years by $55 \%$ and $65 \%$, respectively), the results changed significantly. The model predicted that with $R_{0}=3.10$, the initial 
medRxiv preprint doi: https://doi.org/10.1101/2020.10.21.20216986; this version posted March 4, 2021. The copyright holder for this preprint (which was not certified by peer review) is the author/funder, who has granted medRxiv a license to display the preprint in perpetuity.

It is made available under a CC-BY-NC-ND 4.0 International license.

415 infection doubling time could be 5 days, the peak of epidemic wave could occur after 246 days and it yield

4168,110 infected people in one day. In the first year of the epidemic 2,219,251 people could be infected and

$417 \quad 7,194$ could die.

Table 5 provides the overview of epidemic indicators obtained from the simulations of all five scenarios with $R_{0}=2.46$ and $R_{0}=3.1$. Figures 3. and 4 provide a comparative overview of results of all five simulated scenarios. Panels a) and b) of Fig. 3 show the values of cumulative incidences on a daily

421 basis for $R_{0}=2.46$ and $R_{0}=3.1$, respectively. Panels b) and c) of Fig. 3 show the expected total number of 422 hospitalized patients and patients in intensive care units (ICU) for $R_{0}=2.46$ and $R_{0}=3.1$, respectively. Fig. 4234 provides overview of required hospital capacities e.g. hospital bed occupancy and the occupancy of 424 beds in ICU on daily bases for $R_{0}=2.46$ and $R_{0}=3.1$, respectively. The results show that after applying 425 various measures to slow down the circulation of SARS-Cov-2, the number of newly infected people, 426 hospitalized patients and the occupancy of hospital capacities are the lowest in the situations where 427 rigorous anti-epidemic measures are applied to all population strata (Scenario 2 in Table 5 and in Fig. 3 428 and Fig. 4). Openings of pre-school and elementary school's facilities leads to a visible jump in the 429 number of infected and hospitalized in all strata. This finding clearly shows that children, although least 430 susceptible to developing more severe clinical pictures, are important when transmitting SARS-Cov-2 431 (Scenario 3 in Table 5 and Fig. 3). Opening of the high schools and colleges also leads to a visible 432 increase in the number of newly infected and hospitalized patients, including an increase in the number of 433 deaths (Scenario 5 in Table 5 and Fig. 3). Without the application of any intervention measures, the 434 greatest burden on the health system could be expected 228 days from the beginning of the epidemic at $435 \mathrm{R}_{0}=2.46$ or 168 days at $\mathrm{R}_{0}=3.1$.

437 hospital beds and an additional $20,173(28,740)$ in intensive care units. In the case of Scenario 2, there is 438 a significant slowdown in the epidemic. According to the predictions obtained by the simulation of 439 Scenario 2, after 713 (259) days at the moment of maximum occupancy of hospital capacities, it might be 440 necessary to provide $1,387(3,940)$ beds in COVID-19 hospitals and $784(2,162)$ beds in intensive care 441 units (Fig. 4). 
medRxiv preprint doi: https://doi.org/10.1101/2020.10.21.20216986; this version posted March 4, 2021. The copyright holder for this preprint (which was not certified by peer review) is the author/funder, who has granted medRxiv a license to display the preprint in perpetuity.

It is made available under a CC-BY-NC-ND 4.0 International license .

442

443

444

445

446

447

448

449

450

451

452

453

454

455

456

457

458

459

460

461

462

463

464

\subsection{COVID-19 simulation and disease control by implementing a hypothetical vaccine}

Assuming that the disease is spreading at the basic reproduction number of $R_{0}=2.46$, the herd immunity threshold (when the disease can be expected to slow down and the chain of infection is expected to be broken) would be $59.35 \%$, while at $R_{0}=3.1$, it would be $67.74 \%$. Depending on the efficacy of the potential vaccine, the required vaccination coverage should be $87 \%\left(v_{e}=68 \%\right), 74.19 \%\left(v_{e}=80 \%\right)$, $69.82 \%\left(v_{e}=85 \%\right), 65.94 \%\left(v_{e}=90 \%\right)$ and $95.41 \%\left(v_{e}=71 \%\right), 84.68 \%\left(v_{e}=80 \%\right), 79.70 \%\left(v_{e}=85 \%\right), 75.27 \%$ ( $v_{e}=90 \%$ ) for $\mathrm{R}_{0}=2.46$ and $\mathrm{R}_{0}=3.1$, respectively. The different ways of including vaccination in the SEAIHRD model are detailed in the supplementary material. Fig. 5 shows different scenarios of COVID19 control strategies based solely on vaccination.

\subsection{Results of the model sensitivity analysis}

The results of the sensitivity analysis are presented in tables 6 and 7 . The tables show increased values of input parameters and the percentage of the parameter increase relative to the basic scenario, as well as the values of output results obtained after the simulation of the changed scenario.

\subsection{Results of the model validation}

The model was validated on the most recent historical data (from January 1, 2021 to February 1, 2021). As shown in Table 8. all measures of the prediction quality of deceased due to COVID-19 are low. The average difference between the actual number of people who died of COVID-19 and predicted one is only $2.05 \%$ and the maximum deviation between the predicted and actual number will not exceed $4.82 \%$ with a probability of $95 \%$.

Based on Fig. 6 and Table 9, we can conclude that the SEAIHRD model fits historical data quite well. Pearson's $r$ and coefficient of determination $\left(R^{2}\right)$ have shown strong the linear relationship between real deceased and the number of deaths predicted by SEAIHRD model. 
medRxiv preprint doi: https://doi.org/10.1101/2020.10.21.20216986; this version posted March 4, 2021. The copyright holder for this preprint (which was not certified by peer review) is the author/funder, who has granted medRxiv a license to display the preprint in perpetuity.

It is made available under a CC-BY-NC-ND 4.0 International license .

\section{Conclusions and discussion}

For the needs of this research, we augmented the classic deterministic model by adding the compartments of vaccinated, asymptomatic, hospitalized and latently infected subjects. By adding birth

471 and death rates, we enabled daily fluctuations of the overall simulated population, which brought us

472 closer to the real conditions in which the disease is transmitted. When we assumed that the recovered 473 lose immunity over time, we obtained dynamic oscillations of epidemic waves through susceptible 474 population.

The input values for the parameters used to simulate the COVID-19 were obtained either from literature review or were calculated on the basis of data have taken from the literature and other official sources. Whereas some of these inputs are well documented; other input values are either not so well documented or based on potential subjective opinions (i.e., expert opinion, historical data from epidemic etc.). In any case, well documented or not input values have potential to impact results and, therefore, should be carefully evaluated. The results of conducted sensitivity analysis show that the sources of uncertainty are different for each output considered and it is necessary to consider multiple output variables for a proper assessment of the model. The most influential parameter is $r$ than $\mathrm{R}_{0}$ and $f^{-1}$.

The model was tested on Serbian COVID-19 statistic data and obtained validation results allow us to conclude that the proposed model has good prediction ability and performance. However, although we obtained satisfactory results during the validation of the model, worth noticing also that some of the model parameters were estimated based on available data that might be less precise due to the difficulty of being measured. That could be the reason why the values of some parameters e.g. recovery rate, contact rate, daily infection rate, that are estimated in hospitals may differ from those acquired by this study. For that reasons SEAIHRD model can be used for the long-term rough predictions of the epidemic. Obtained long-term predictions reflect the general dynamic of the outbreak and are especially useful for the healthcare system workers and governmental officials.

When we simulated different disease control scenarios of the COVID-19 epidemic based on non493 pharmaceutical intervention measures, scenario number 2 proved to be the most effective approach to 494 the disease control, because it implemented the most comprehensive anti-epidemic measures (entire 
medRxiv preprint doi: https://doi.org/10.1101/2020.10.21.20216986; this version posted March 4, 2021. The copyright holder for this preprint (which was not certified by peer review) is the author/funder, who has granted medRxiv a license to display the preprint in perpetuity.

It is made available under a CC-BY-NC-ND 4.0 International license .

495

496

497

498

499

500

501

502

503

504

505

506

507

508

509

510

511

512

513

514

515

516

517

518

519

520

country lock down). However, the basic problem of this approach is the feasibility and practicability to maintain the measures in the long term.

The model predicted that students, children and younger school-age generations have an important role in transmitting COVID-19, especially if they come into contact with a more vulnerable population. The model showed that, in the case of returning school children of all ages to schools, an increase of $10.48 \%$ in the estimated deaths and $12.16 \%$ of the number of infected is possible, when compared to the conditions before opening of the schools (Scenarios 2 and 4). However, most dead and seriously diseased people are found in the older population. This is particularly important when planning intervention measures, especially when deciding on which restrictions to be lifted and how (opening schools, students' return to faculties etc.). The model predicted that COVID-19 has a potential to spread rapidly and linger in population. Due to a large number of the infected persons and duration of the disease, there are significant needs for hospital capacities, especially in the conditions when the disease is suppressed by implementing partly relaxed anti-epidemic measures, or in the case of absence of any measures. According to the prediction, without the application of any intervention measures, at the moment of the greatest load, depending of actual $R_{0}$, the health system should provide $42,351\left(R_{0}=2.46\right)$ hospital beds for the care of the patients and an additional 20,733 in intensive care units. On the other hand, in the case of the application of the strictest anti-epidemic measures, the needs decrease to only 1,387 beds in COVID-19 hospitals and additional 784 beds in intensive care units. In the case of continued implementation of current measures, which are significantly less intense than the measures applied at the beginning of the epidemic, it is necessary to provide 3,537 beds in COVID-19 hospitals and 1,945 beds in intensive care units in the entire country. The model also shows that the needs for hospital capacities decline with the ending of the first epidemic wave, since daily incidence decreases and during the second and third waves it never reaches the initial peaks, but these needs still remain substantial. For example, in the case of Scenario 1, at the top of the second epidemic wave, it is necessary to provide 11,845 beds in COVID-19 hospitals and 6,378 in intensive care units, which makes $27.96 \%$ and $30,76 \%$ of the required capacities of the first wave of the epidemic. 
medRxiv preprint doi: https://doi.org/10.1101/2020.10.21.20216986; this version posted March 4, 2021. The copyright holder for this preprint (which was not certified by peer review) is the author/funder, who has granted medRxiv a license to display the preprint in perpetuity.

It is made available under a CC-BY-NC-ND 4.0 International license.

Based on the cyclical patterns of the epidemic waves and duration of simulated epidemics, the model predicted that the disease has a potential to linger in population and that it will most probably have

523 a seasonal pattern. Therefore, potential vaccines can have an enormous potential and significance for

524 COVID-19 control. Depending on the efficacy of future vaccines, the disease can be stopped and curbed

525 almost solely by implementing the measure of vaccination. However, the necessary conditions for these

526 predictions and expectations are the efficacy of potential vaccines and the ability of a health systems to

527 implement vaccination to a satisfactory extent and rapidly, especially with regards to the most sensitive

528 categories of population. Depending on the $R_{0}$, a vaccine that would have an efficacy $\geq 68-71 \%$ could

529 stop the pandemic and break the chain of infection. However, even vaccines with lower efficacy could be

530 useful as they would significantly reduce the number of cases and deaths, especially if used in

531 combination with the other disease control measures. The effects of vaccination depend primarily on: 1.

532 Efficacy of available vaccine(s), 2. Prioritization of the population categories for vaccination, and 3.

533 Overall vaccination coverage of the population, assuming that the vaccine(s) develop solid immunity in

534 vaccinated individuals. With expected basic reproduction number of Ro=2.46 and vaccine efficacy of $53568 \%$, an $87 \%$ - coverage would be sufficient to stop the virus circulation. The required minimal vaccination coverage should be $87 \%\left(v_{e}=68 \%\right), 74.19 \%\left(v_{e}=80 \%\right), 69.82 \%\left(v_{e}=85 \%\right)$ and $95.41 \%\left(v_{e}=71 \%\right), 84.68 \%$

$537\left(v_{e}=80 \%\right), 79.70 \%\left(v_{e}=85 \%\right)$ for $\mathrm{R}_{0}=2.46$ and $\mathrm{R}_{0}=3.1$, respectively. The minimum daily vaccination rate 538 should be $0.47 \%$ for vaccines with an efficiency of $85 \%$, and $0.59 \%$ for vaccines with an efficiency of $53968 \%$

Based on the obtained results, we can conclude that at this point, without the application of 541 specific pharmaceutical products, COVID-19 suppression is highly dependent on the basic reproduction 542 number $\left(R_{0}\right)$, and that more intensive contacts and relaxed measures can result in a dramatic spread of 543 the virus. The choice of intervention measures depends on the feasibility of their implementation and their 544 efficacy in different social contexts. COVID-19 will likely have to be suppressed in this way for a certain 545 period of time. This will most probably last until sufficient quantities of a reliable and effective vaccine are 546 available, and thereafter until optimal vaccination coverage is achieved. 
medRxiv preprint doi: https://doi.org/10.1101/2020.10.21.20216986; this version posted March 4, 2021. The copyright holder for this preprint (which was not certified by peer review) is the author/funder, who has granted medRxiv a license to display the preprint in perpetuity.

It is made available under a CC-BY-NC-ND 4.0 International license .

547 Funding: This research did not receive any specific grant from funding agencies in the public, 548 commercial, or not-for-profit sectors.

549 References

550 [1] World Health Organization (WHO), Coronavirus disease (COVID-19) outbreak situation. 2020.

551 https://www.who.int/emergencies/diseases/ novel-coronavirus-2019, [accessed 18 August 2020].

552 [2] https://covid19.rs, 2020, [accessed 18 August 2020].

553 [3] Wangping J, Ke H, Yang S, Wenzhe C, Shengshu W, Shanshan Y, Miao L. Extended SIR prediction 554 of the epidemics trend of COVID-19 in Italy and compared with Hunan, China. Frontiers in Medicine 2020; $555 \quad 7: 169$.

556 [4] Kucharski AJ, Russell TW, Diamond C, Liu Y, Edmunds J, Funk S, Davies N. Early dynamics of 557 transmission and control of COVID-19: a mathematical modelling study. The Lancet infectious diseases 558 2020. Doi: 10.1016/S1473-3099(20) 30144-4.

559 [5] Matt J. Keeling, Pejman Rohani. Modelling Infectious Diseases in Humans and Animals, Princeton 560 University Press, 3 Market Place, Woodstock, Oxfordshire OX20 1SY, p. 8-10.

561 [6] Kermack, W. and A. McKendrick (1927). A contribution to the mathematical theory of epidemics. 562 Proceedings of the Royal Society. A 115, p. 700-721.

563 [7] Barnes B. and G. R. Fulford. Mathematical modelling with case studies Using Maple ${ }^{\text {TM }}$ and MATLAB, 564 CRC Press Taylor \& Francis Group 6000 Broken Sound Parkway NW, Suite 300, Boca Raton, FL 334875652742 , p. 100-102.

566 [8] Imperial College COVID-19 Response Team. Report 9: Impact of non-pharmaceutical interventions 567 (NPIs) to reduce COVID-19 mortality and healthcare demand; 2020.

568 https://www.imperial.ac.uk/media/imperial-college/medicine/sph/ide/gida-fellowships/Imperial-College-

569 COVID19-NPI-modelling-16-03-2020.pdf.

570 [9] Wu Z, Googan JMM. Characteristics of and important lessons from the coronavirus disease 2019 571 (COVID-19) outbreak in China: Summary of a Report of $72 \square 314$ Cases from the Chinese Center for 572 Disease Control and Prevention. JAMA. 2020;323(13):1239-1242. Doi:10.1001/jama.2020.2648.

573 [10] Emilia Vynnycky, Richard G. White with an introduction by Paul E.M. Fine. An Introduction to 574 Infectious Disease Modelling. Oxford University Press Inc., New York @ Oxford University Press; 2010. 
medRxiv preprint doi: https://doi.org/10.1101/2020.10.21.20216986; this version posted March 4, 2021. The copyright holder for this preprint (which was not certified by peer review) is the author/funder, who has granted medRxiv a license to display the preprint in perpetuity.

It is made available under a CC-BY-NC-ND 4.0 International license .

575 [12] European Centre for Disease Prevention and Control. Immune responses and immunity to SARS-

576 CoV-2; 2020. https://www.ecdc.europa.eu/en/covid-19/latest-evidence/immune-responses; [accessed 18

577 August 2020].

578 [13] Woelfel R, Corman VM, Guggemos W, Seilmaier M, Zange S, Mueller MA, et al. Clinical presentation

579 and virological assessment of hospitalized cases of coronavirus disease 2019 in a travel-associated

580 transmission cluster. medRxiv. 2020; https://doi.org/10.1101/2020.03.05.20030502.

581 [14] Liu W, Liu L, Kou G, Zheng Y, Ding Y, Ni W, et al. Evaluation of Nucleocapsid and Spike Protein-

582 based ELISAs for detecting antibodies against SARS-CoV-2. medRxiv. 2020.

583 https://doi.org/10.1101/2020.03.16.20035014.

584 [15] Long Q-x, Deng H-j, Chen J, Hu J, Liu B-z, Liao P, et al. Antibody responses to SARS-CoV-2 in

COVID-19 patients: the perspective application of serological tests in clinical practice. medRxiv.

586 https://doi.org/10.1101/2020.03.18.20038018.

587 [16] Zhao J, Yuan Q, Wang H, Liu W, Liao X, Su Y, et al. Antibody responses to SARS-CoV-2 in patients

588 of novel coronavirus disease 2019. medRxiv. 2020; https://doi.org/10.1101/2020.03.02.20030189.

589 [17] Okba NMA, Muller MA, Li W, Wang C, Geurtsvan Kessel CH, Corman VM, et al. SARS-CoV-2

590 specific antibody responses in COVID-19 patients. medRxiv. 2020;

591 https://doi.org/10.1101/2020.03.18.20038059.

592 [18] Zhao J, Yuan Q, Wang H, Liu W, Liao X, Su Y, et al. Antibody responses to SARS-CoV-2 in patients

593 of novel coronavirus disease 2019. medRxiv. 2020; https://doi.org/10.1101/2020.03.02.20030189.

594 [19] Kellam P, Barclay W. The dynamics of humoral immune responses following SARS-CoV-2 infection 595 and the potential for reinfection. The Journal of general virology. 2020 May 20.

596 [20] Kissler et al. Projecting the transmission dynamics of SARS-CoV-2 through the postpandemic period, 597 Science 10.1126/science.abb5793 (2020).

598 [21] K. A. Callow et al. The time course of the immune response to experimental coronavirus infection of 599 man. Epidemiol. Infect. 105, 435-446 (1990)

600 [22] J. M. Dan et al. Immunological memory to SARS-CoV-2 assessed for up to 8 months after infection 601 Science 371, eabf4063 (2021). DOI: 10.1126/science.abf4063. 
medRxiv preprint doi: https://doi.org/10.1101/2020.10.21.20216986; this version posted March 4, 2021. The copyright holder for this preprint (which was not certified by peer review) is the author/funder, who has granted medRxiv a license to display the preprint in perpetuity.

It is made available under a CC-BY-NC-ND 4.0 International license .

602 [23] K.-H. Chan et al. Cross-reactive antibodies in convalescent SARS patients' sera against the 603 emergingnovel human coronavirus EMC (2012) byboth immunofluorescent and neutralizingantibody tests

604 J. Infect. 67, 130-140 (2013).

605 [24] Sheila F Lumley et al. Antibodies to SARS-CoV-2 are associated with protection against reinfection. 606 medRxiv preprint doi: https://doi.org/10.1101/2020.11.18.20234369.

607 [25] Gerardo Chowell, James M. Hyman, Lu'ıs M. A. Bettencourt, Carlos Castillo-Chavez. Mathematical 608 and Statistical Estimation Approaches in Epidemiology, ISBN 978-90-481-2312-4, Doi 10.1007/978-90609 481-2313-1, Springer Dordrecht Heidelberg London New York; 2009.

610 [26] Michael Thrusfield. Veterinary epidemiology. Third edition. Blackwell Science Ltd, a Blackwell 611 Publishing company; 2007.

612 [27] Marco D'Arienzo, Angela Coniglio. Assessment of the SARS-CoV-2 basic reproduction number, R0, 613 based on the early phase of COVID-19 outbreak in Italy. Biosafety and Health 2(2020) 57-59.

614 [28] Demografski pregled 2017. Broj: 68/2018, https://www.minrzs.gov.rs/sites/default/files/2019615 01/demografski_pregled_68.pdf; [accessed 15 July 2020].

616 [29] The World Bank. World Developments Indicators;

617 https://www.google.com/publicdata/explore?ds=d5bncppjof8f9_\&met_y=sp_dyn_le00_in\&idim=country:S 618 RB:HRV:BIH\&hl=en\&dl=en\#!ctype=I\&strail=false\&bcs=d\&nselm=h\&met_y=sp_dyn_le00_in\&scale_y=lin\& 619 ind_y=false\&rdim=world\&idim=country:SRB\&ifdim=world\&hl=en_US\&dl=en\&ind=false; [accessed 25

620 August 2020].

621 [30] Byrne AW et al. Inferred duration of infectious period of SARS-CoV-2: rapid scoping review and 622 analysis of available evidence for asymptomatic and symptomatic COVID-19 cases. BMJ Open 623 2020;10:e039856. doi:10.1136/ bmjopen-2020-039856].

624 [31] Shujuan Ma et al., Epidemiological parameters of coronavirus disease 2019: a pooled analysis of 625 publicly reported individual data of 1155 cases from seven countries. medRxiv 2020;preprint doi: 626 https://doi.org/10.1101/2020.03.21.20040329].

627 [32] Robert Verity et al. Estimates of the severity of coronavirus disease 2019: a model-based analysis. 628 Lancet Infect Dis 2020; 20: 669-77, https://doi.org/10.1016/ S1473-3099(20)30243-7 
medRxiv preprint doi: https://doi.org/10.1101/2020.10.21.20216986; this version posted March 4, 2021. The copyright holder for this preprint (which was not certified by peer review) is the author/funder, who has granted medRxiv a license to display the preprint in perpetuity.

It is made available under a CC-BY-NC-ND 4.0 International license .

629 [33] Roberto Pastor-Barriuso et al. Infection fatality risk for SARS-CoV-2: a nationwide 630 seroepidemiological study in the noninstitutionalized population of Spain. medRxiv. 2020; preprint doi: 631 https://doi.org/10.1101/2020.08.06.20169722.

632 [34] Marco D'Arienzo, Angela Coniglio. Assessment of the SARS-CoV-2 basic reproduction number, R0, 633 based on the early phase of COVID-19 outbreak in Italy. Biosafety and Health 2(2020) 57-59.

634 [35] McAloon C. et al. Incubation period of COVID-19: a rapid systematic review and meta-analysis of 635 observational research. BMJ Open 2020;10:e039652. doi:10.1136/ bmjopen-2020-039652.

636 [36] Pierre-Yves Boëlle at al. Trajectories of Hospitalization in COVID-19 Patients: An Observational 637 Study in France. J. Clin. Med. 2020, 9, 3148; doi:10.3390/jcm9103148.

638 [37] Natalie M. Linton at al. Incubation Period and Other EpidemiologicalCharacteristics of 2019 Novel 639 Coronavirus Infections with Right Truncation: A Statistical Analysis of Publicly Available Case Data. J. 640 Clin. Med. 2020, 9(2), 538; https://doi.org/10.3390/jcm9020538.

641 [38] Ma S, Zhang J, Zeng M, et al. Epidemiological parameters of coronavirus disease 2019: a pooled 642 analysis of publicly reported individual data of 1155 cases from seven countries. medRxiv 2020.

643 [39] Michael A. Johansson et al. SARS-CoV-2 Transmission From People Without COVID-19 Symptoms. $644 \quad J A M A$ Network Open. 2021;4(1):e2035057. doi:10.1001/jamanetworkopen.2020.35057.

645 [40] Alex Viguerie, Guillermo Lorenzo, Ferdinando Auricchio, Davide Baroli, Thomas J.R. Hughes, Alessia 646 Patton, Alessandro Reali, Thomas E. Yankeelov, Alessandro Veneziani. Simulating the spread of COVID64719 via a spatially-resolved susceptible-exposed-infected-recovered-deceased (SEIRD) model with 648 heterogeneous diffusion. Applied Mathematics Letters 111 (2021) 106617.

649 [41] David Baud, Xiaolong Qi, Karin Nielsen-Saines, Didier Musso, Léo Pomar, Guillaume Favre. Real 650 estimates of mortality following COVID-19 infection. The Lancet. 2020 Jul; 20(7): 773. 651 Doi: 10.1016/S1473-3099(20)30195-X.

652 [42] Charles F. Manski, Francesca Molinari. Estimating the COVID-19 infection rate: Anatomy of an 653 inference problem. Journal of Econometrics. https://doi.org/10.1016/j.jeconom.2020.04.041.

654 [43] WHO. Q\&A: Influenza and COVID-19 - similarities and differences. 655 https://www.who.int/westernpacific/news/q-a-detail/q-a-similarities-and-differences-covid-19-and656 influenza. [accessed 18 August 2020]. 
medRxiv preprint doi: https://doi.org/10.1101/2020.10.21.20216986; this version posted March 4, 2021. The copyright holder for this preprint (which was not certified by peer review) is the author/funder, who has granted medRxiv a license to display the preprint in perpetuity.

It is made available under a CC-BY-NC-ND 4.0 International license .

657 [44] CDC. https://www.cdc.gov/coronavirus/2019-ncov/hcp/planning-scenarios.html; [accessed 18 August 658 2020].

659 [45] BMJ 2020; 368. Covid-19: identifying and isolating asymptomatic people helped eliminate virus in 660 Italian village. doi: https://doi.org/10.1136/bmj.m1165.

661 [46] Buitrago-Garcia D, Egli-Gany D, Counotte MJ, Hossmann S, Imeri H, Ipekci AM, et al. (2020)

662 Occurrence and transmission potential of asymptomatic and presymptomatic SARS-CoV-2 infections: A 663 living systematic review and metaanalysis. PLoS Med 17(9): e1003346. https://doi. 664 org/10.1371/journal.pmed.1003346.

665 [47] Eric A Meyerowitz et al. Towards an accurate and systematic characterisation of persistently 666 asymptomatic infection with SARS-CoV-2. Lancet Infect Dis 2020. https://doi.org/10.1016/ S1473$6673099(20) 30837-9$.

668 [48] CEBM- The Centre for Evidence-Based Medicine develops, promotes and disseminates better 669 evidence for healthcare. Estimating the infection fatality ratio in England. https://www.cebm.net/covid670 19/estimating-the-infection-fatality-ratio-in-england/; [accessed 9 October 2020].

671 [49] Wood, S. N. Did COVID-19 infections decline before UK lockdown? ArXiv:2005.02090 [q-Bio, Stat]. 672 http://arxiv.org/abs/2005.02090.

673 [50] Selene Ghisolfi, Ingvild Almås, Justin Sandefur, Tillmann von Carnap, Jesse Heitner, Tessa Bold. 674 Predicted COVID-19 Fatality Rates Based on Age, Sex, Comorbidities, and Health System Capacity. 675 2020Jun.https://www.cgdev.org/sites/default/files/predicted-covid-19-fatality-rates-based-age-sex-

676 comorbidities-and-health-system-capacity.pdf.

677 [51] B. Martınez-Lo'pez et al. A novel spatial and stochastic model to evaluate the within and between 678 farm transmission of classical swine fever virus: II Validation of the model. / Veterinary Microbiology 155 679 (2012) 21-32 doi:10.1016/j.vetmic.2011.08.008.

680 [52] Karsten et al. Monte Carlo simulation of classical swine feverepidemics and control II. Validation of 681 the model. Veterinary Microbiology 108 (2005) 199-205. doi:10.1016/j.vetmic.2005.04.008. 
medRxiv preprint doi: https://doi.org/10.1101/2020.10.21.20216986; this version posted March 4, 2021. The copyright holder for this preprint (which was not certified by peer review) is the author/funder, who has granted medRxiv a license to display the preprint in perpetuity.

It is made available under a CC-BY-NC-ND 4.0 International license .

Tables

686

Table 1. Structure of different population strata in the Republic of Serbia [23]

\begin{tabular}{lrr}
\hline Stratum & Population & Percentage of total population \\
\hline Younger than 7 years & 356,377 & $5.10 \%$ \\
Elementary school & 550,527 & $7.88 \%$ \\
Secondary school & 249,455 & $3.57 \%$ \\
Students & 241,698 & $3.46 \%$ \\
Employed & $2,197,065$ & $31.46 \%$ \\
Pensioners & $1,715,152$ & $24.56 \%$ \\
Others & $1,672,330$ & $23.95 \%$
\end{tabular}

687

688

689 Table 2. Age structure of the population of the Republic of Serbia and expected percentage of 690 hospitalized patients, patients in intensive care, and death rate caused by COVID-19.

\begin{tabular}{|c|c|c|c|c|c|}
\hline $\begin{array}{l}\text { Population } \\
\text { age } \\
\text { groups }\end{array}$ & ${ }^{*}$ Population & $\begin{array}{l}\text { Percentage } \\
\text { of total } \\
\text { population }\end{array}$ & $\begin{array}{l}{ }^{* \star} \text { Expected } \% \text { of } \\
\text { hospitalized } \\
\text { patients }(\sigma)\end{array}$ & $\begin{array}{l}{ }^{* \star} \text { Expected } \% \text { of patients } \\
\text { whose treatment requires } \\
\text { intensive care }\end{array}$ & $\begin{array}{l}{ }^{* \star \star \star} \text { Infection } \\
\text { fatality rate IFR } \\
\text { (male/female) }\end{array}$ \\
\hline $0-9$ & 458,199 & $6.56 \%$ & $0.00 \%$ & $5.00 \%$ & $0.04 \% ; 0.01 \%$ \\
\hline $10-19$ & 445,481 & $6.38 \%$ & $0.04 \%$ & $5.00 \%$ & $0.00 \% ; 0.02 \%$ \\
\hline $20-29$ & $1,028,226$ & $14.73 \%$ & $1.04 \%$ & $5.00 \%$ & $0.00 \% ; 0.01 \%$ \\
\hline $30-39$ & 951,615 & $13.63 \%$ & $3.43 \%$ & $5.00 \%$ & $0.00 \% ; 0.05 \%$ \\
\hline $40-49$ & 968,854 & $13.88 \%$ & $4.25 \%$ & $6.30 \%$ & $0.08 \% ; 0.04 \%$ \\
\hline $50-59$ & 963,229 & $13.79 \%$ & $8.16 \%$ & $12.20 \%$ & $0.33 \% ; 0.20 \%$ \\
\hline $60-69$ & 815,244 & $11.68 \%$ & $11.80 \%$ & $27.40 \%$ & $1.62 \% ; 0.62 \%$ \\
\hline $70-79$ & 696,045 & $9.97 \%$ & $16.60 \%$ & $43.20 \%$ & $6.11 \% ; 2.68 \%$ \\
\hline 80- & 655,711 & $9.39 \%$ & $18.40 \%$ & $70.90 \%$ & $16.40 \% ; 6.49 \%$ \\
\hline
\end{tabular}


medRxiv preprint doi: https://doi.org/10.1101/2020.10.21.20216986; this version posted March 4, 2021. The copyright holder for this preprint (which was not certified by peer review) is the author/funder, who has granted medRxiv a license to display the preprint in perpetuity.

It is made available under a CC-BY-NC-ND 4.0 International license .

Table 3. SEAIHRD model parameters

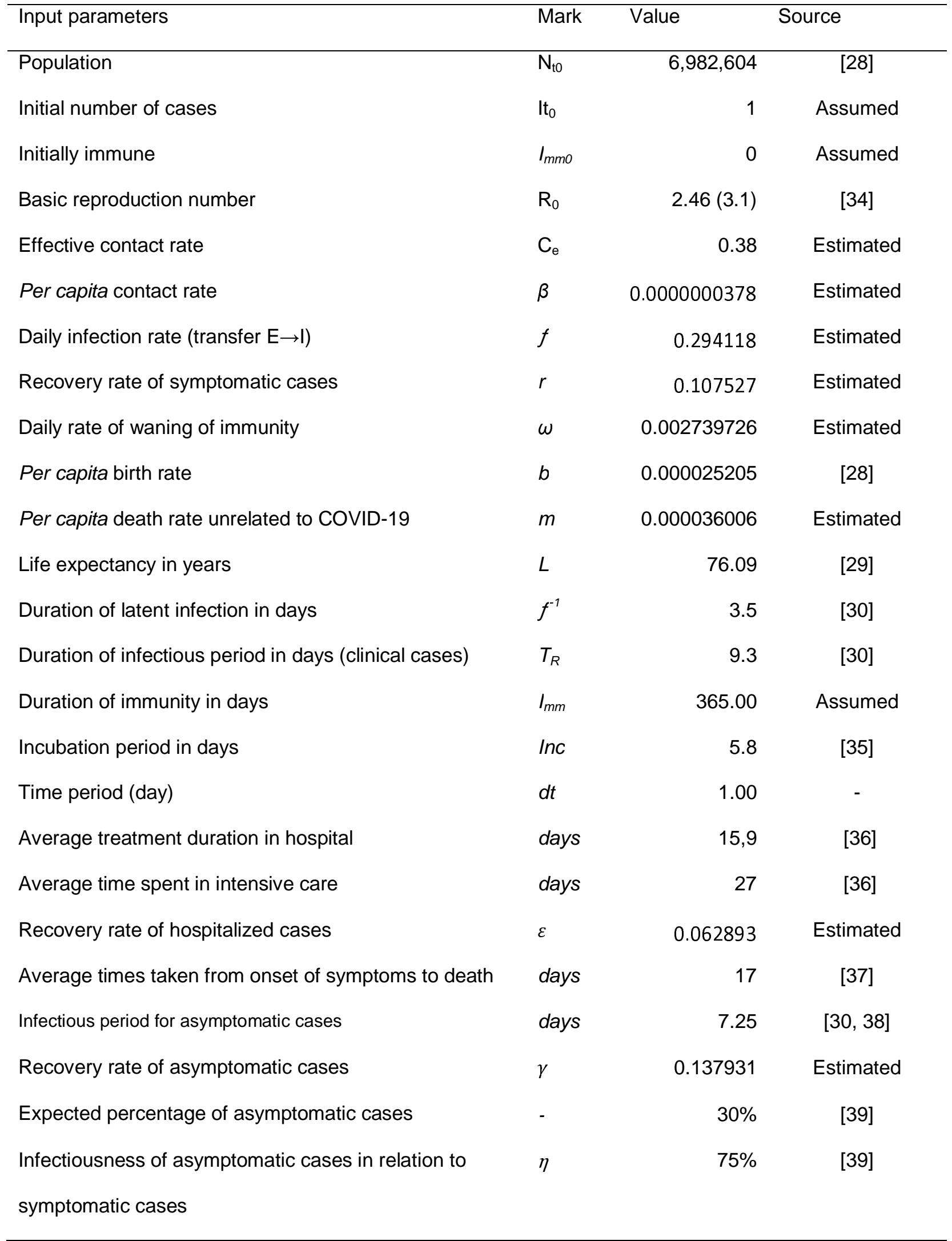


medRxiv preprint doi: https://doi.org/10.1101/2020.10.21.20216986; this version posted March 4, 2021. The copyright holder for this preprint (which was not certified by peer review) is the author/funder, who has granted medRxiv a license to display the preprint in perpetuity.

It is made available under a CC-BY-NC-ND 4.0 International license .

694 Table 4. Description of different simulated non-pharmaceutical intervention scenarios

\begin{tabular}{|c|c|c|}
\hline Mark & Scenario & Scenario description \\
\hline SC1 & $\begin{array}{l}\text { Base-case } \\
\text { scenario }\end{array}$ & $\begin{array}{l}\text { The population relies on development of herd immunity. No anti-epidemic } \\
\text { measures are implemented. }\end{array}$ \\
\hline SC2 & $\begin{array}{l}\text { Lock down of } \\
\text { the entire } \\
\text { country }\end{array}$ & $\begin{array}{l}\text { Pre-schools, schools, and colleges are fully closed - reduction in contacts at } \\
\text { educational institutions by } 75 \% \text {; reduction in contacts in workplaces by } 50 \% \text {; } \\
\text { reduction in contacts of the elderly (older than } 65 \text { ) by } 50 \% \text { at } R_{0}=2.46 \text { or by } \\
65 \% \text { at } R_{0}=3.10 \text {; physical distancing of the unemployed population and in } \\
\text { public places - reduction in contacts by } 45 \% \text { at } R_{0}=2.46 \text { ) or by } 55 \% \text { at } R_{0}= \\
3.10 \text {. }\end{array}$ \\
\hline SC3 & $\begin{array}{l}\text { Partial } \\
\text { lockdown of } \\
\text { the country - I }\end{array}$ & $\begin{array}{l}\text { Elementary and pre-school educational institutions are open. High schools } \\
\text { and colleges are closed. Reduction in contacts by } 75 \% \text { at colleges and high- } \\
\text { schools; reduction in contacts in workplaces by } 50 \% \text {; reduction in contacts of } \\
\text { the elderly (older than } 65 \text { ) by } 60 \% \text { at } \mathrm{R}_{0}=2.46 \text { or by } 65 \% \text { at } \mathrm{R}_{0}=3.10 \text {; social } \\
\text { distancing of the unemployed population and in public places - reduction in } \\
\text { contacts by } 40 \% \text { at } \mathrm{R}_{0}=2.46 \text { or by } 55 \% \text { at } \mathrm{R}_{0}=3.10 \text {. }\end{array}$ \\
\hline SC4 & $\begin{array}{l}\text { Partial } \\
\text { lockdown of } \\
\text { the country - II }\end{array}$ & $\begin{array}{l}\text { Colleges are closed - reduction in contacts by } 75 \% \text {; reduction in contacts in } \\
\text { the workplace by } 50 \% \text {; reduction in contacts of the elderly (older than } 65 \text { ) by } \\
60 \% \text { at } R_{0}=2.46 \text { or by } 65 \% \text { at } R_{0}=3.10 \text {; social distancing of the unemployed } \\
\text { population and in public places - reduction in contacts by } 40 \% \text { at } R_{0}=2.46 \text { or } \\
\text { by } 55 \% \text { at } R_{0}=3.10 \text {. }\end{array}$ \\
\hline SC5 & $\begin{array}{l}\text { Partial } \\
\text { lockdown of } \\
\text { the country - III }\end{array}$ & $\begin{array}{l}\text { Reduction in contacts in the workplace by } 50 \% \text {; reduction in contacts of the } \\
\text { elderly (older than } 65 \text { ) by } 60 \% \text { at } R_{0}=2.46 \text { or by } 65 \% \text { at } R_{0}=3.10 \text {; social } \\
\text { distancing of the unemployed population and in public places - reduction in } \\
\text { contacts by } 40 \% \text { at } R_{0}=2.46 \text { or by } 55 \% \text { at } R_{0}=3.10 \text {. }\end{array}$ \\
\hline
\end{tabular}




\begin{tabular}{|c|c|c|c|c|c|c|c|c|c|c|}
\hline Scenario mark & \multicolumn{2}{|c|}{ SC1 } & \multicolumn{2}{|c|}{ SC2 } & \multicolumn{2}{|c|}{ SC3 } & \multicolumn{2}{|c|}{ SC4 } & \multicolumn{2}{|c|}{ SC5 } \\
\hline $\begin{array}{l}\text { Basic } \\
\text { reproductive } \\
\text { number }\end{array}$ & $R_{0}=2.64$ & $R_{0}=3.1$ & $R_{0}=2.64$ & $R_{0}=3.1$ & $R_{0}=2.64$ & $\mathrm{R}_{0}=3.1$ & $R_{0}=2.64$ & $R_{0}=3.1$ & $R_{0}=2.64$ & $\mathrm{R}_{0}=3.1$ \\
\hline $\begin{array}{l}\text { Cumulative } \\
\text { incidence }(\mathrm{Cl})\end{array}$ & $6,229,144$ & $7,133,221$ & 308,581 & $2,219,251$ & $1,286,227$ & $2,419,079$ & $1,375,416$ & $2,489,197$ & $1,408,262$ & $2,514,936$ \\
\hline $\begin{array}{l}\text { Apparent } \mathrm{Cl} \\
\text { Overall }\end{array}$ & $4,360,401$ & $4,993,254$ & 216,007 & $1,553,476$ & 900,359 & $1,693,355$ & 962,791 & $1,742,438$ & 985,783 & $1,760,456$ \\
\hline $\begin{array}{l}\text { hospitalized } \\
\text { Overall in }\end{array}$ & 278,781 & 320,567 & 13,970 & 98,337 & 56,631 & 105,930 & 60,319 & 108,554 & 61,685 & 109,538 \\
\hline intensive care & 85,633 & 98,333 & 4,260 & 29,753 & 17,085 & 32,058 & 18,202 & 32,855 & 18,612 & 33,147 \\
\hline Overall deaths & 20,894 & 23,951 & 1,031 & 7,194 & 4,113 & 7,754 & 4,383 & 7,948 & 4,483 & 8,018 \\
\hline
\end{tabular}

698

699 Table 6. Results of the model sensitivity analysis of individual parameters used in the model

\begin{tabular}{cccccc}
\hline $\begin{array}{c}\text { Model } \\
\text { parameter } \\
\text { mark }\end{array}$ & $\begin{array}{c}\text { Change } \\
\text { relative to the } \\
\text { basic scenario }\end{array}$ & $\mathrm{Cl}$ & Deaths $\left(\mathrm{D}_{\text {th }}\right)$ & $\begin{array}{c}\text { Change in } \mathrm{Cl} \\
\text { relative to the } \\
\text { basic scenario }\end{array}$ & $\begin{array}{c}\text { Change in } \mathrm{D}_{\text {th }} \\
\text { relative to the } \\
\text { basic scenario }\end{array}$ \\
\hline$R_{0}$ & $5 \%$ & $6,398,486$ & 21,470 & $2.72 \%$ & $2.75 \%$ \\
$R_{0}$ & $10 \%$ & $6,553,978$ & 21,998 & $5.21 \%$ & $5.28 \%$ \\
$R_{0}$ & $25 \%$ & $6,982,604$ & 23,782 & $12.10 \%$ & $13.82 \%$ \\
$f^{-1}$ & $5 \%$ & $6,224,056$ & 19,885 & $0.08 \%$ & $4.83 \%$ \\
$f^{-1}$ & $10 \%$ & $6,219,502$ & 18,968 & $0.15 \%$ & $9.22 \%$ \\
$f^{-1}$ & $25 \%$ & $6,208,481$ & 16,666 & $0.33 \%$ & $20.24 \%$ \\
$r$ & $5 \%$ & $6,068,299$ & 20,351 & $2.58 \%$ & $2.60 \%$ \\
$r$ & $10 \%$ & $5,908,223$ & 19,811 & $5.15 \%$ & $5.18 \%$ \\
$r$ & $25 \%$ & $5,425,721$ & 18,182 & $12.90 \%$ & $12.98 \%$ \\
\hline
\end{tabular}

700

701 
medRxiv preprint doi: https://doi.org/10.1101/2020.10.21.20216986; this version posted March 4, 2021. The copyright holder for this preprint (which was not certified by peer review) is the author/funder, who has granted medRxiv a license to display the preprint in perpetuity.

It is made available under a CC-BY-NC-ND 4.0 International license .

702 Table 7 . Results of the model sensitivity analysis of group of parameters using a perturbation up to $25 \%$

\begin{tabular}{cccccc}
\hline Model parameter mark & $\begin{array}{c}\text { Change relative } \\
\text { to the basic } \\
\text { scenario }\end{array}$ & $\mathrm{Cl}$ & $\begin{array}{c}\text { Deaths } \\
\left(\mathrm{D}_{\text {th }}\right)\end{array}$ & $\begin{array}{c}\text { Change in } \mathrm{Cl} \\
\text { relative to the } \\
\text { basic scenario }\end{array}$ & $\begin{array}{c}\text { Change in } \mathrm{D}_{\text {th }} \\
\text { relative to the } \\
\text { basic scenario }\end{array}$ \\
\hline$R_{0}, f^{-1}, r$ & $5 \%$ & $6,242,433$ & 19,948 & $-0.21 \%$ & $4.53 \%$ \\
$R_{0}, f^{-1}, r$ & $10 \%$ & $6,257,685$ & 19,093 & $-0.46 \%$ & $8.62 \%$ \\
$R_{0}, f^{-1}, r$ & $25 \%$ & $6,321,339$ & 16,984 & $-1.48 \%$ & $18.71 \%$ \\
$R_{0}, \beta, f^{-1}, r, b, m, \gamma, \varepsilon, \eta, \omega$, & $25 \%$ & $6,147,725$ & 13,203 & $1.31 \%$ & $36.81 \%$ \\
$\bar{\tau}_{d}$ & & & & \\
\hline
\end{tabular}

703

704 Table 8. Measures of the prediction quality

\begin{tabular}{ccccccrr}
\hline & MAE & \%Error & MSE & RMSE & Normalized MAE & Normalized MSE & Max Deviation \\
\hline Deceased & 73 & $2.04 \%$ & $7,212.20$ & 84.92 & $2.05 \%$ & $0.06 \%$ & $4.82 \%$
\end{tabular}

705

706 Table 9. Regression statistics

\begin{tabular}{ccccc}
\hline Multiple R & R Square & Adjusted R Square & Standard Error & Observations \\
\hline 0.981678289 & 0.963692263 & 0.963124954 & 86.24143528 & 66 \\
\hline
\end{tabular}

707

708

709

710

711

712

713

714

715

716

717

718

719

720 
medRxiv preprint doi: https://doi.org/10.1101/2020.10.21.20216986; this version posted March 4, 2021. The copyright holder for this preprint (which was not certified by peer review) is the author/funder, who has granted medRxiv a license to display the preprint in perpetuity.

It is made available under a CC-BY-NC-ND 4.0 International license .

\section{$721 \quad$ Figures}

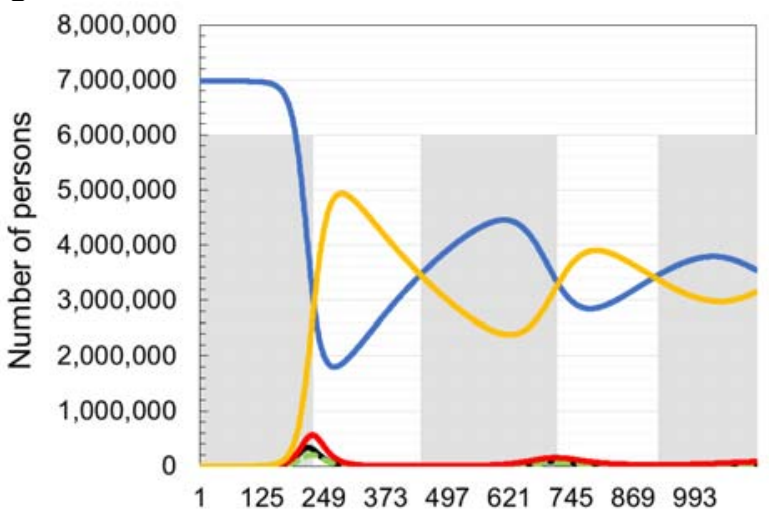

Days since the epidemic onset

$$
-\mathrm{S}-\mathrm{E}-\mathrm{A}-\mathrm{A}-\mathrm{R}
$$

a) Distribution of the total number of the susceptible, latently infected, asymptomatic infectious individuals, infected and recovered on a daily basis since the epidemic onset $\left(R_{0}=2.46\right)$

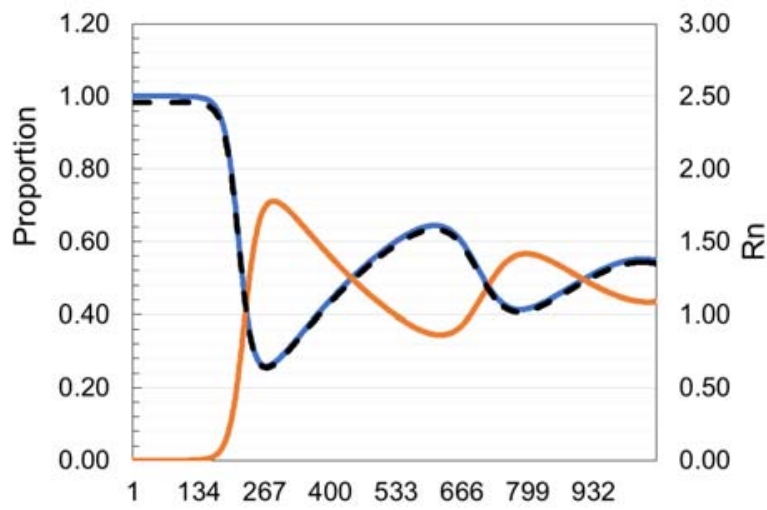

Days since the epidemic onset

$$
-\mathrm{s}-\mathrm{r}-\cdot \mathrm{Rn}
$$

c) Daily fluctuations of the susceptible, recovered and net disease transmission rates $\left(\mathrm{R}_{0}=2.46\right)$

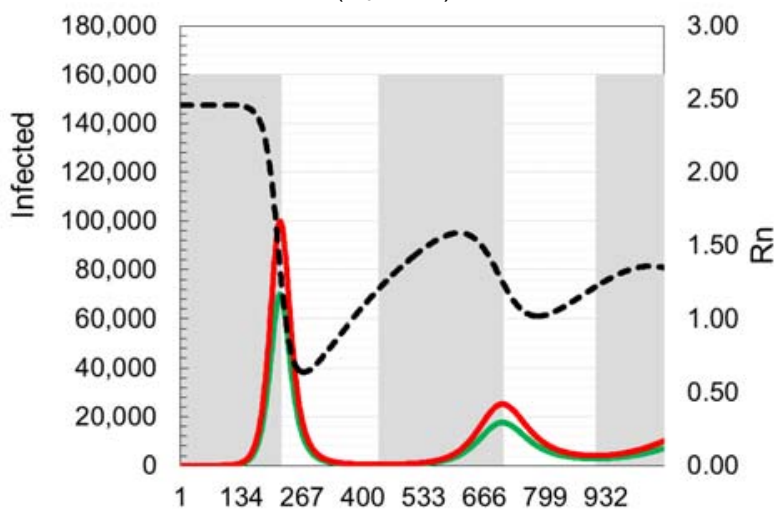

Days since the epidemic onset

$$
\text { -App_Inc -True_Inc --Rn }
$$

e) Daily fluctuations of apparent incidence, true incidence and net disease transmission rates $\left(R_{0}=2.46\right)$

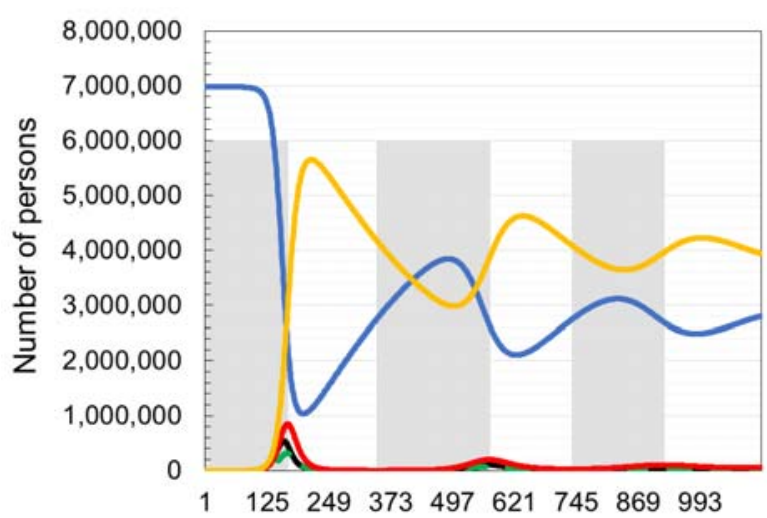

Days since the epidemic onset

$$
\text { - S - E - - A - I - R }
$$

b) Distribution of the total number of the susceptible, latently infected, asymptomatic infectious individuals, infected and recovered on a daily basis since the epidemic onset $\left(R_{0}=3.1\right)$

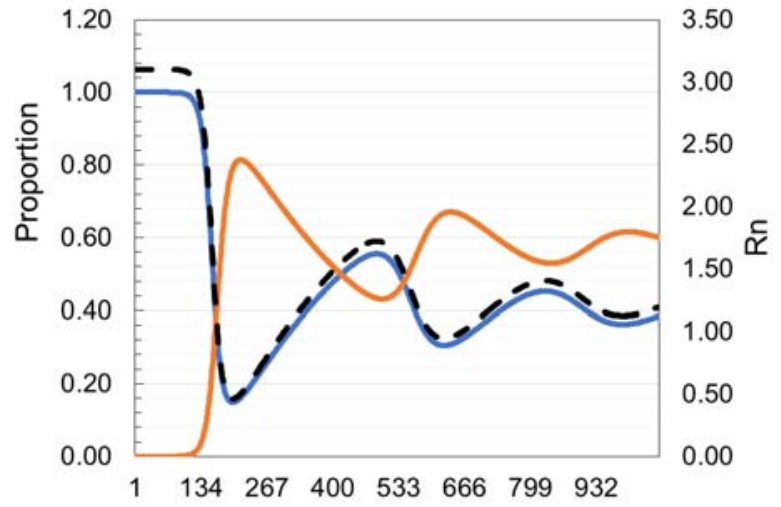

Days since the epidemic onset

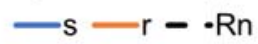

d) Daily fluctuations of the susceptible, recovered and net disease transmission rates $\left(R_{0}=3.1\right)$

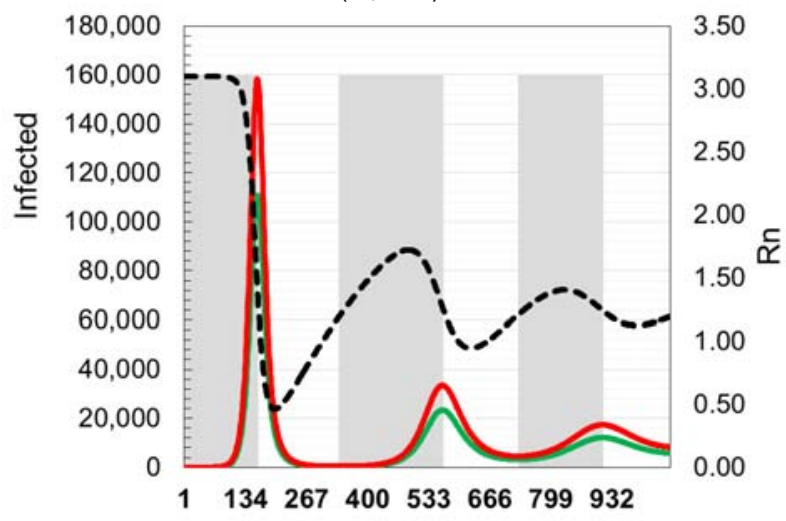

Days since the epidemic onset

-App_Inc -True_Inc --Rn

f) Daily fluctuations of apparent incidence, true incidence and net disease transmission rates $\left(R_{0}=2.46\right)$

722 Fig.1 Model prediction of latently infected, asymptomatic infectious individuals, infected, recovered and 723 daily fluctuations of $R_{n}$. 
medRxiv preprint doi: https://doi.org/10.1101/2020.10.21.20216986; this version posted March 4, 2021. The copyright holder for this preprint (which was not certified by peer review) is the author/funder, who has granted medRxiv a license to display the preprint in perpetuity.

It is made available under a CC-BY-NC-ND 4.0 International license .

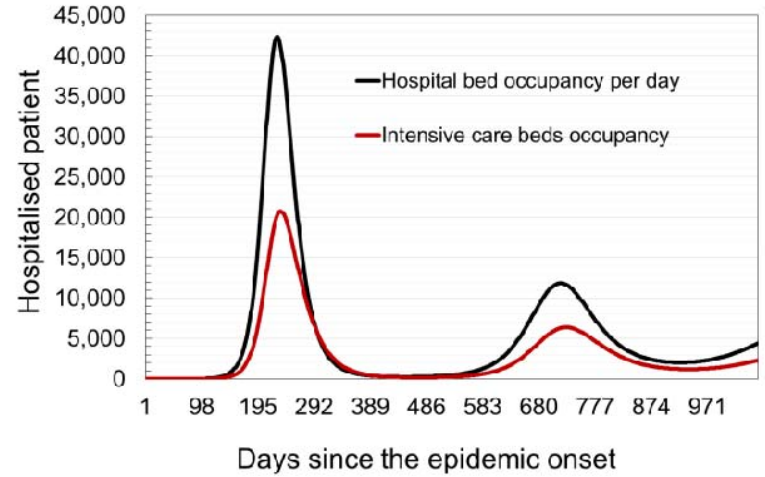

a) Necessary hospital capacities $\left(R_{0}=2.46\right)$

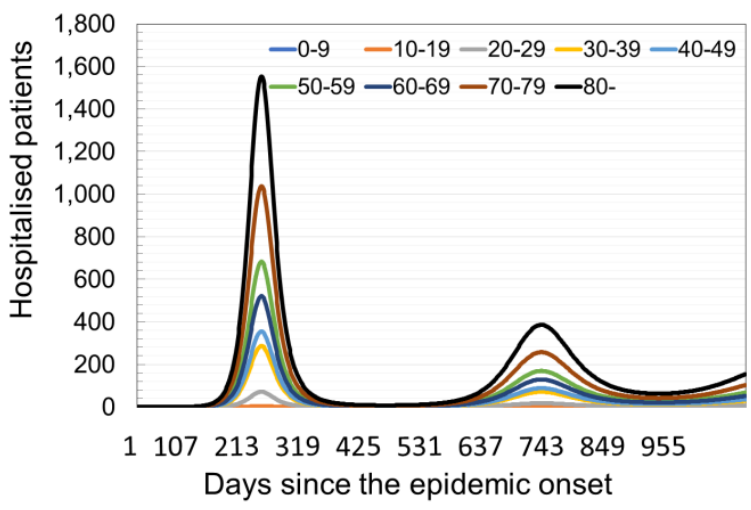

c) Age structure of hospitalized patients $\left(R_{0}=2.46\right)$

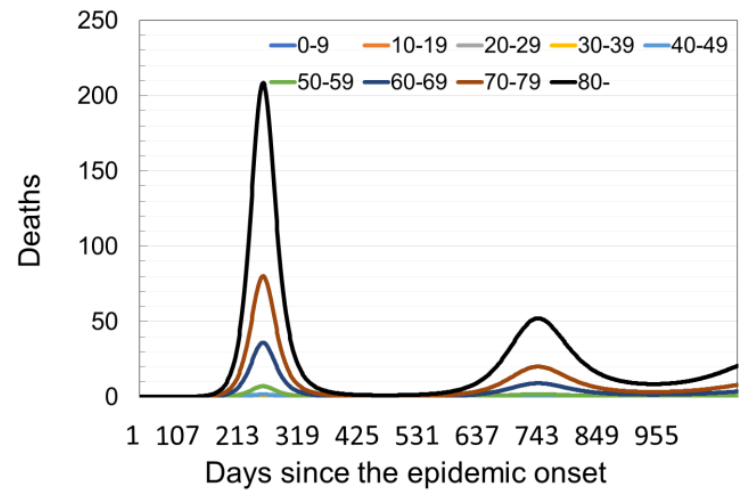

e) Expected age structure of the dead $\left(R_{0}=2.46\right)$

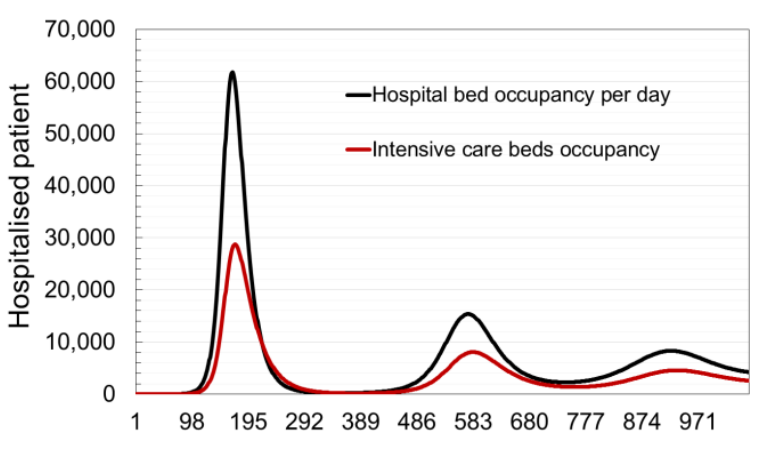

Days since the epidemic onset

b) Necessary hospital capacities $\left(R_{0}=3.1\right)$

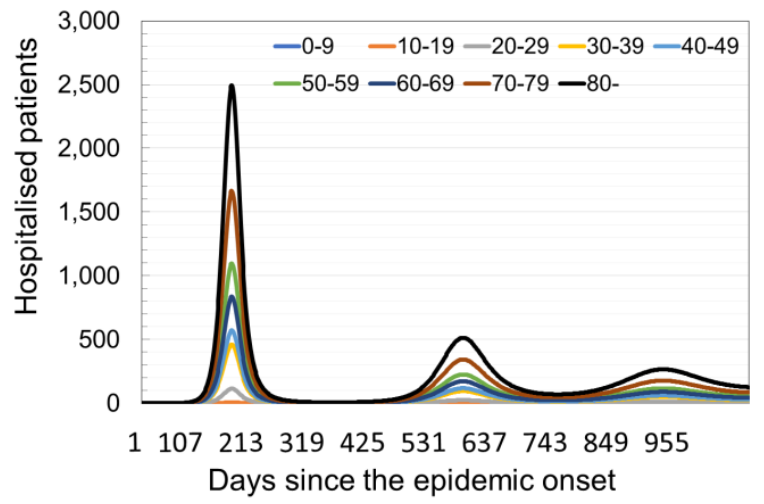

d) Age structure of hospitalized patients $\left(R_{0}=3.1\right)$

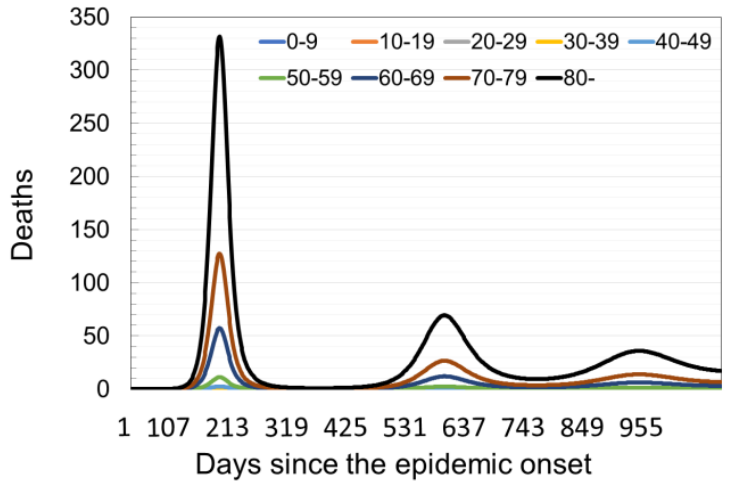

f) Expected age structure of the dead $(\mathrm{Ro}=3.1)$ measures. 
medRxiv preprint doi: https://doi.org/10.1101/2020.10.21.20216986; this version posted March 4, 2021. The copyright holder for this preprint (which was not certified by peer review) is the author/funder, who has granted medRxiv a license to display the preprint in perpetuity.

It is made available under a CC-BY-NC-ND 4.0 International license .

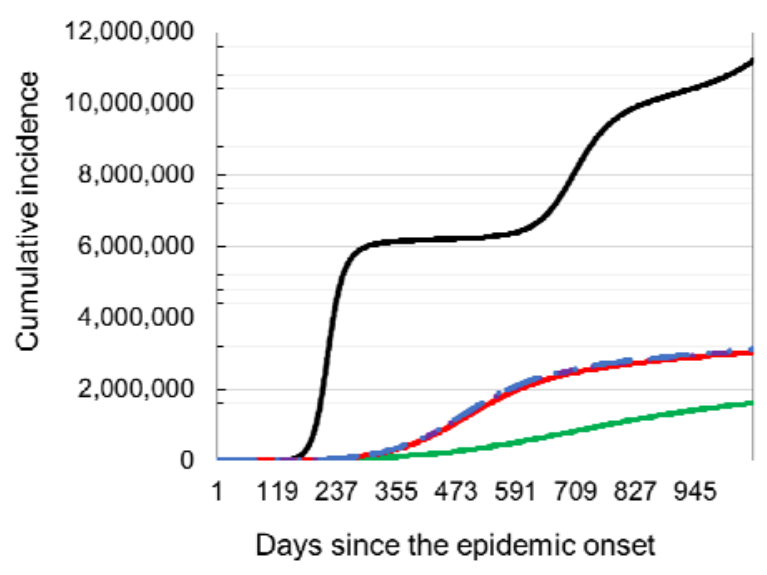

a) Comparative overview of cumulative incidences $(\mathrm{Cl})$. Results obtained from simulated scenarios 1-5 $\left(R_{0}=2.46\right)$

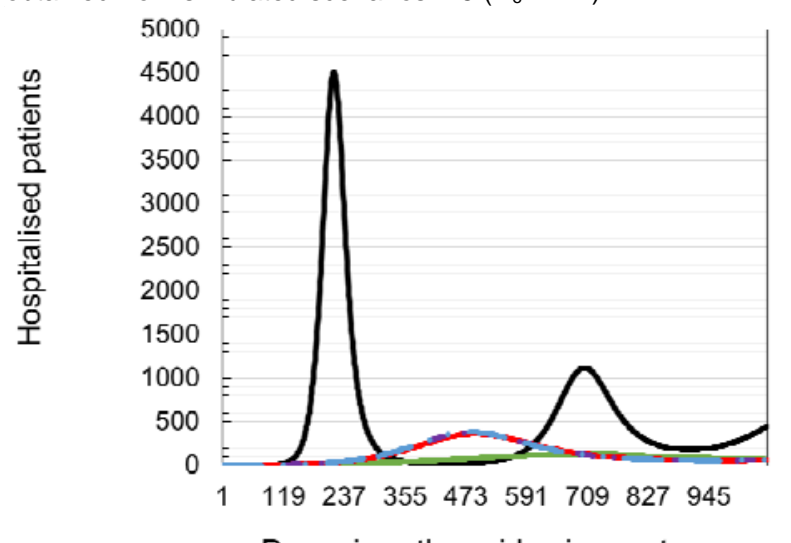

Days since the epidemic onset

- SC1 - SC2 - SC3 - -SC4 - SC5

c) Comparative overview of hospitalized patients on a daily basis. Results obtained from simulated scenarios 1-5 $\left(R_{0}=2.46\right)$

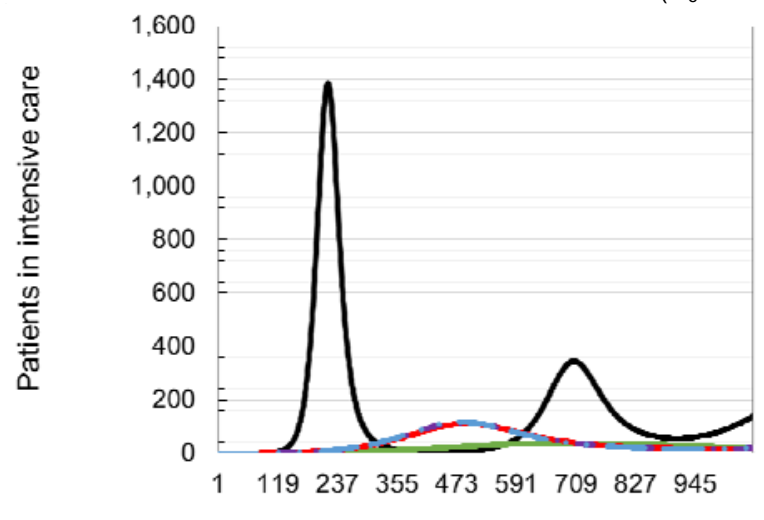

Days since the epidemic onset

- SC1 - SC2 - SC3 - -SC4 - SC5

e) Comparative overview of expected number of patients in intensive care on a daily basis. Results obtained from simulated scenarios $1-5$ with $R_{0}=2.46$

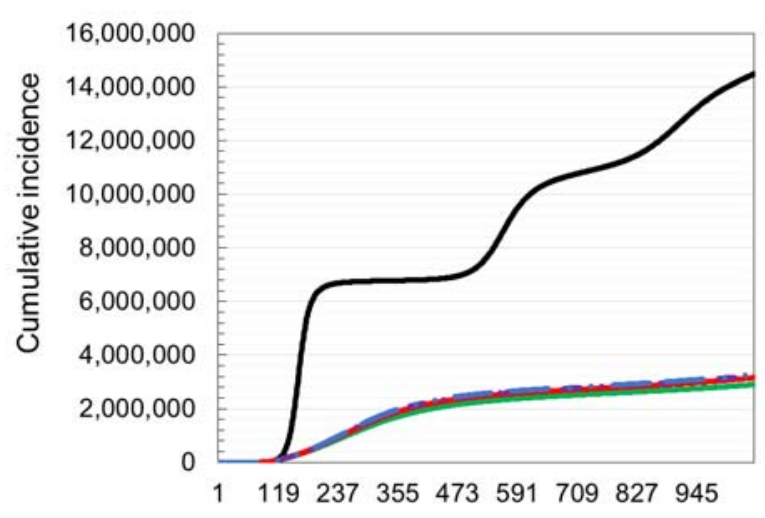

Days since the epidemic onset

- SC1 - SC2 - SC3 - - SC4 - SC5

b) Comparative overview of cumulative incidences $(\mathrm{Cl})$. Results obtained from simulated scenarios $1-5\left(R_{0}=3.1\right)$

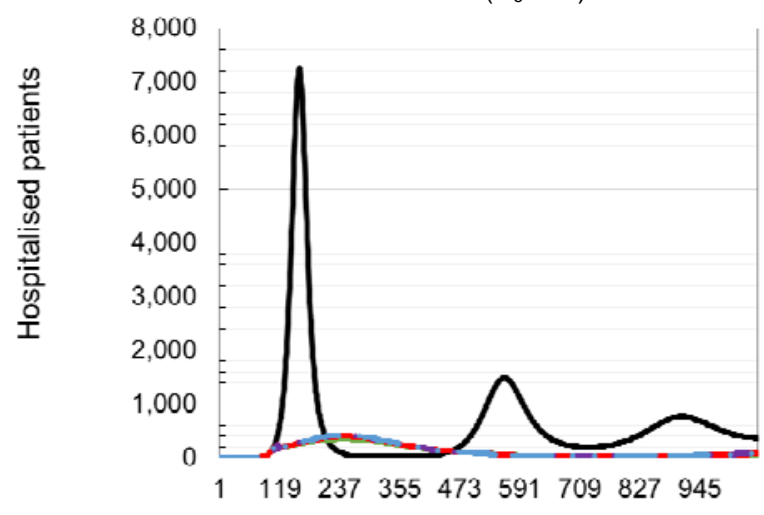

Days since the epidemic onset

—SC1 - SC2 - SC3 - -SC4 - SC5

d) Comparative overview of hospitalized patients on a daily basis. Results obtained from simulated scenarios 1-5 $\left(\mathrm{R}_{0}=3.1\right)$

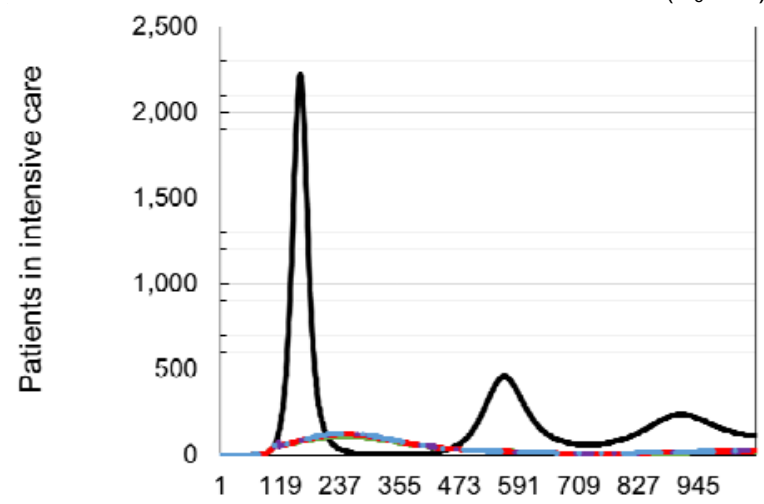

Days since the epidemic onset

- SC1 - SC2 - SC3 - . SC4 - SC5

f) Comparative overview of expected number of patients in intensive care on a daily basis. Results obtained from simulated scenarios $1-5$ with $R_{0}=3.1$

729 Fig.3 Model prediction of expected number of hospitalized patient and patient in intensive care. 
medRxiv preprint doi: https://doi.org/10.1101/2020.10.21.20216986; this version posted March 4, 2021. The copyright holder for this preprint (which was not certified by peer review) is the author/funder, who has granted medRxiv a license to display the preprint in perpetuity.

It is made available under a CC-BY-NC-ND 4.0 International license .

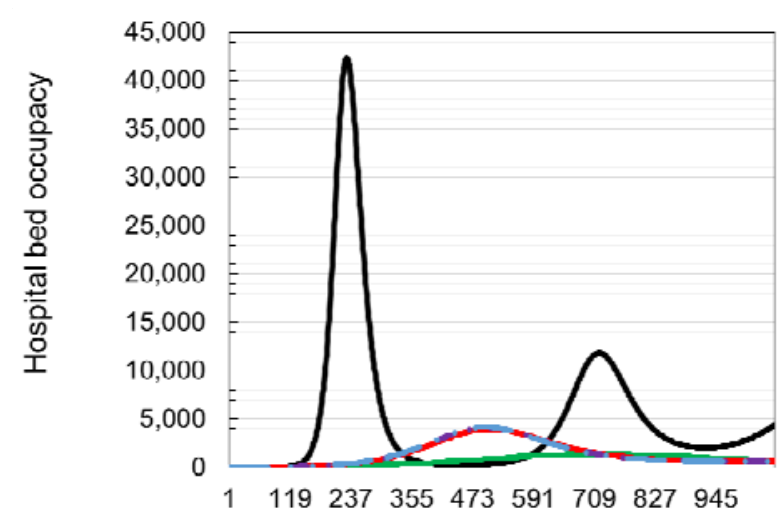

Days since the epidemic onset

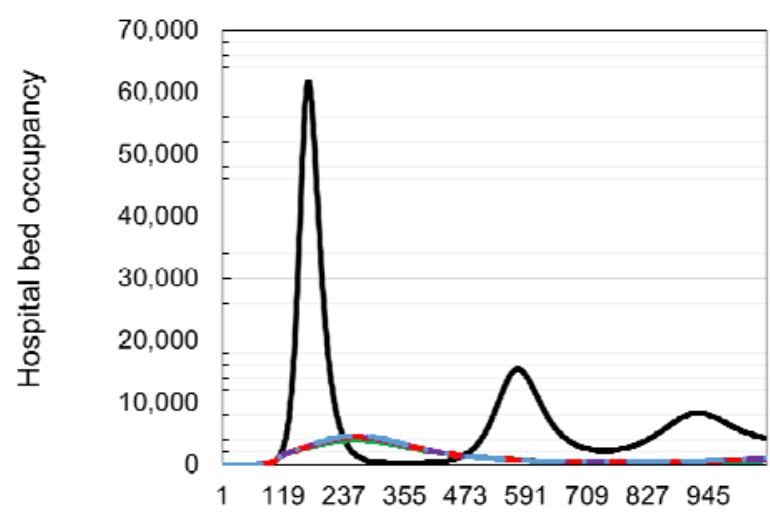

Days since the epidemic onset

- SC1 - SC2 - SC3 - -SC4 - SC5

a) Comparative overview of hospital bed occupancy $\left(R_{0}=2.46\right)$

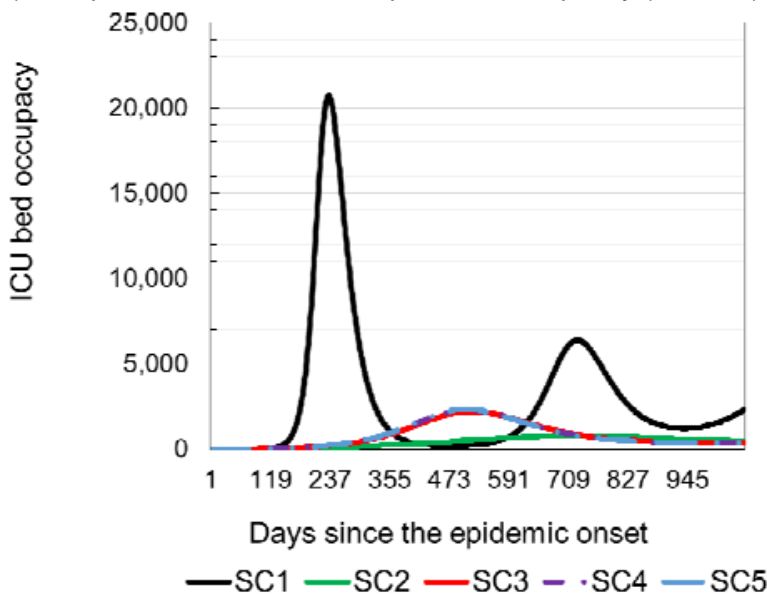

b Comparative overview of hospital bed occupancy $\left(R_{0}=3.1\right)$

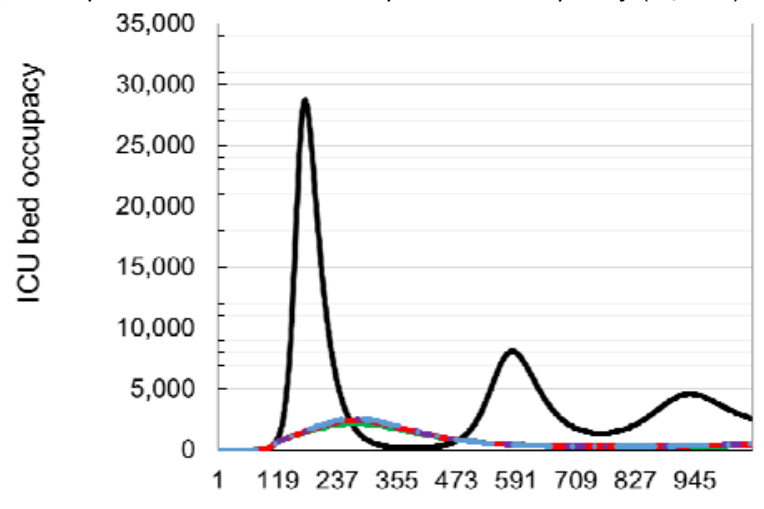

Days since the epidemic onset

$-\mathrm{SC} 1-\mathrm{SC} 2-\mathrm{SC} 3-\cdot \mathrm{SC} 4-\mathrm{SC} 5$

c) Comparative overview of ICU bed occupancy $(\mathrm{Ro}=2.46)$

d) Comparative overview of ICU bed occupancy $(R o=3.1)$

Fig. 4 Model prediction of required hospital capacities needed to treat patients with COVID-19. 
medRxiv preprint doi: https://doi.org/10.1101/2020.10.21.20216986; this version posted March 4, 2021. The copyright holder for this preprint (which was not certified by peer review) is the author/funder, who has granted medRxiv a license to display the preprint in perpetuity.

It is made available under a CC-BY-NC-ND 4.0 International license .

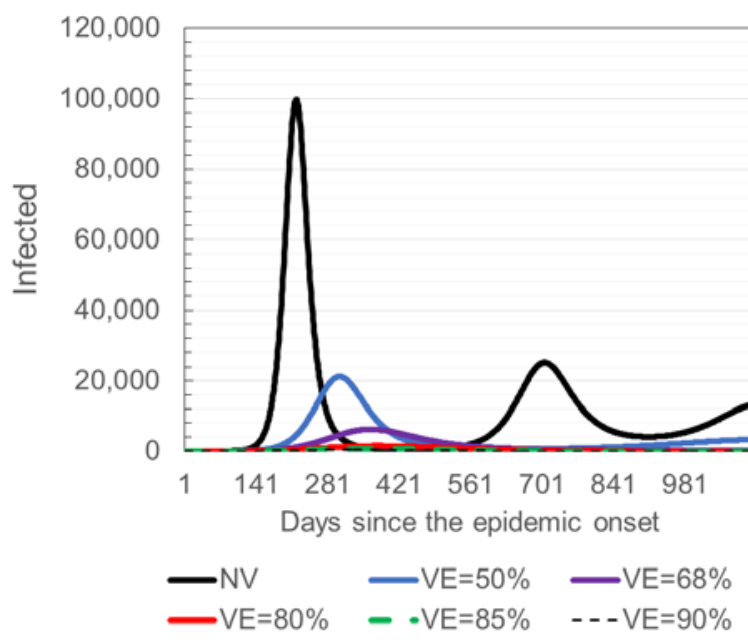

a) Comparative overview of daily incidences $\left(R_{0}=2.46\right)$.

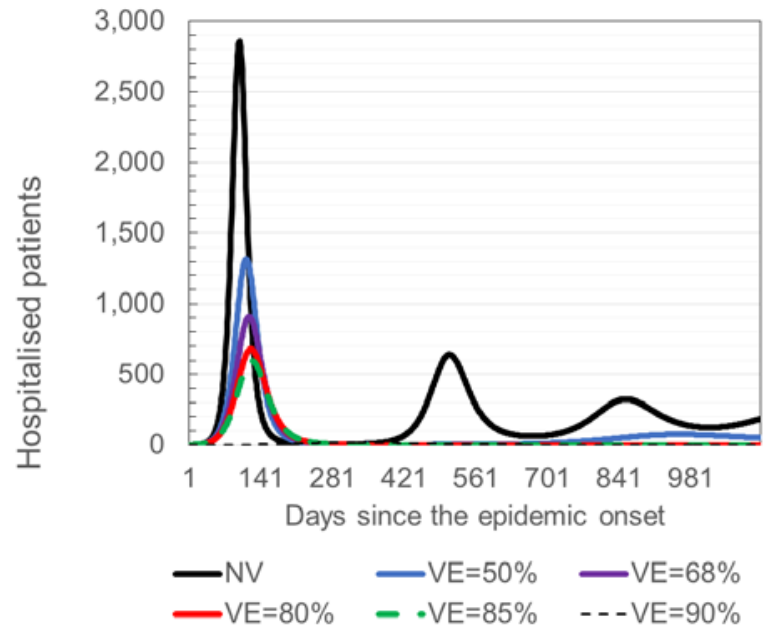

c) Comparative overview of hospitalized patients $\left(R_{0}=2.46\right)$.

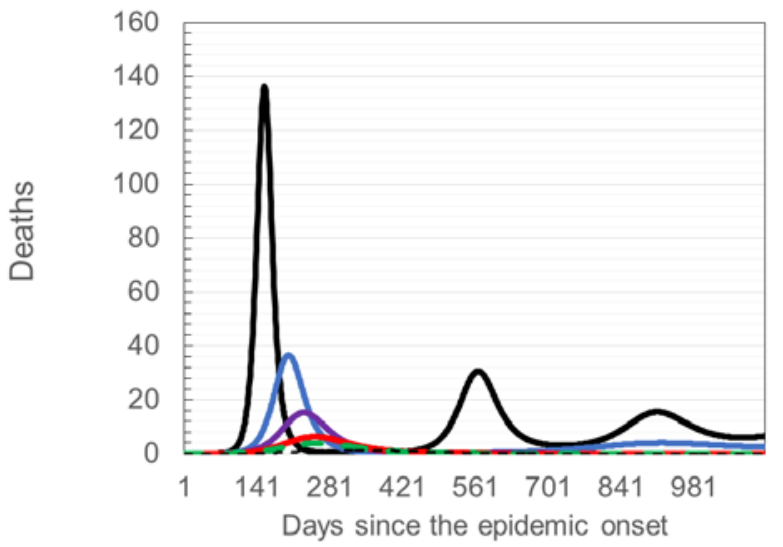

$$
\begin{array}{lll}
-\mathrm{NV} & -\mathrm{VE}=50 \% & -\mathrm{VE}=68 \% \\
-\mathrm{VE}=80 \% & -\cdot \mathrm{VE}=85 \% & -\mathrm{VE}=90 \%
\end{array}
$$

e) Comparative overview of deaths $(\mathrm{Ro}=2.46)$

$N V$-without vaccination and any non-pharmaceutical intervention $\mathrm{R}_{0}=3.1$ ).

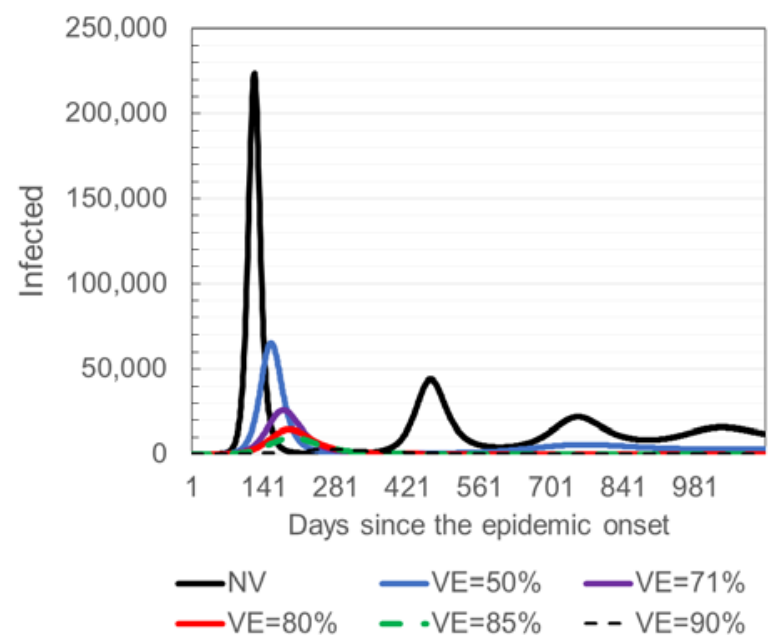

b) Comparative overview of daily incidences $\left(R_{0}=3.1\right)$.

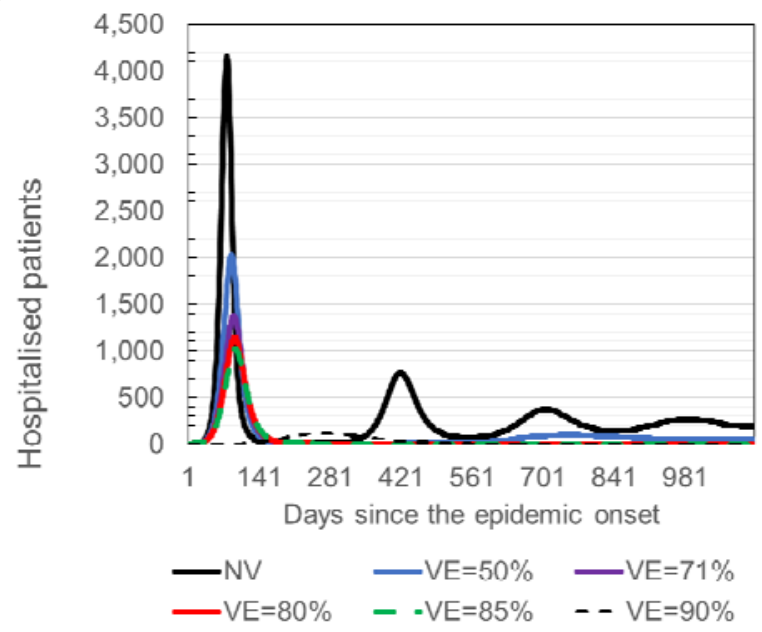

d) C) Comparative overview of hospitalized patients $\left(R_{0}=3.1\right)$.

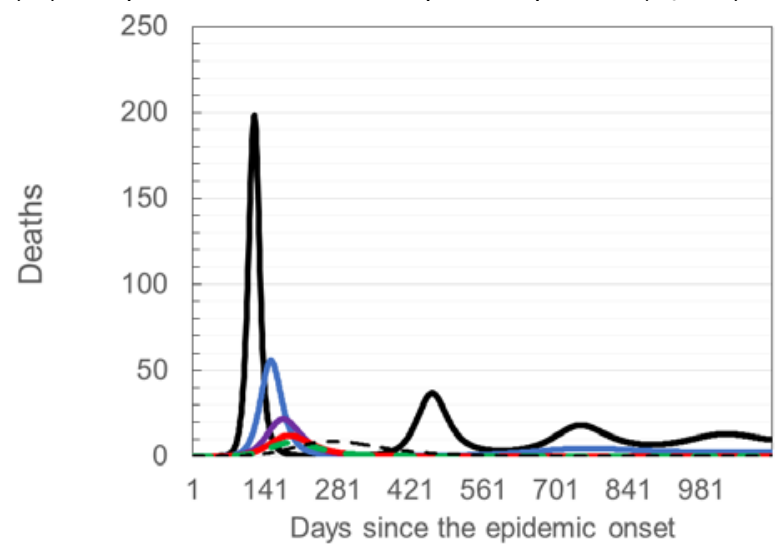

$$
\begin{array}{lll}
-\mathrm{NV} & -\mathrm{VE}=50 \% & -\mathrm{VE}=71 \% \\
-\mathrm{VE}=80 \% & -\cdot \mathrm{VE}=85 \% & --\mathrm{VE}=90 \%
\end{array}
$$

f) Comparative overview of deaths $(\mathrm{Ro}=3.1)$

Fig. 5 Results of simulated COVID-19 control based solely on vaccination, scenarios $6-9\left(R_{0}=2.46\right.$ and 
medRxiv preprint doi: https://doi.org/10.1101/2020.10.21.20216986; this version posted March 4, 2021. The copyright holder for this preprint (which was not certified by peer review) is the author/funder, who has granted medRxiv a license to display the preprint in perpetuity.

\section{It is made available under a CC-BY-NC-ND 4.0 International license .}

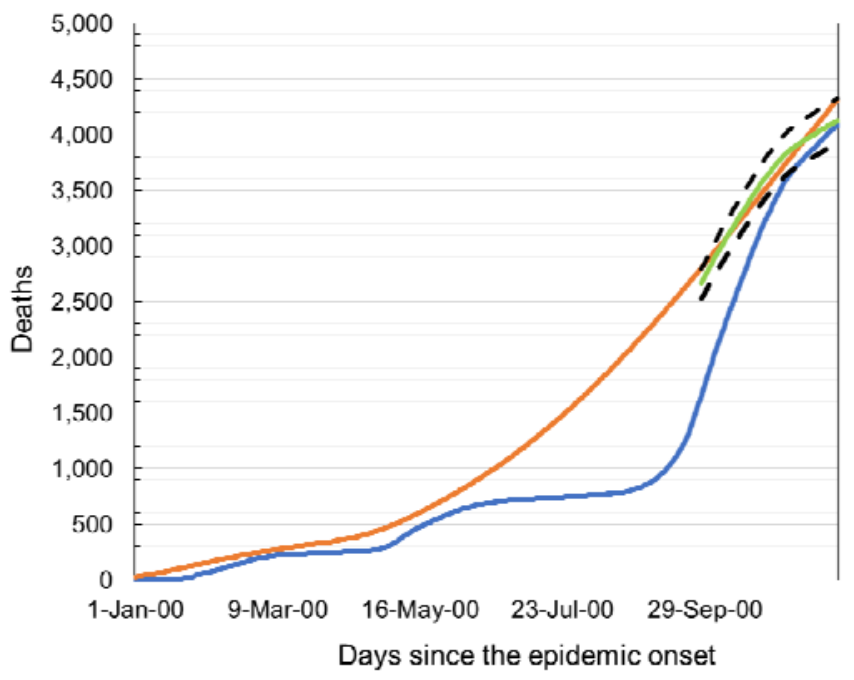

739 Fig. 6. The observed number of deceased individuals (blue), number of deaths modeled with SEAIHRD

740 model (yellow) and predicted number of deaths (green). 


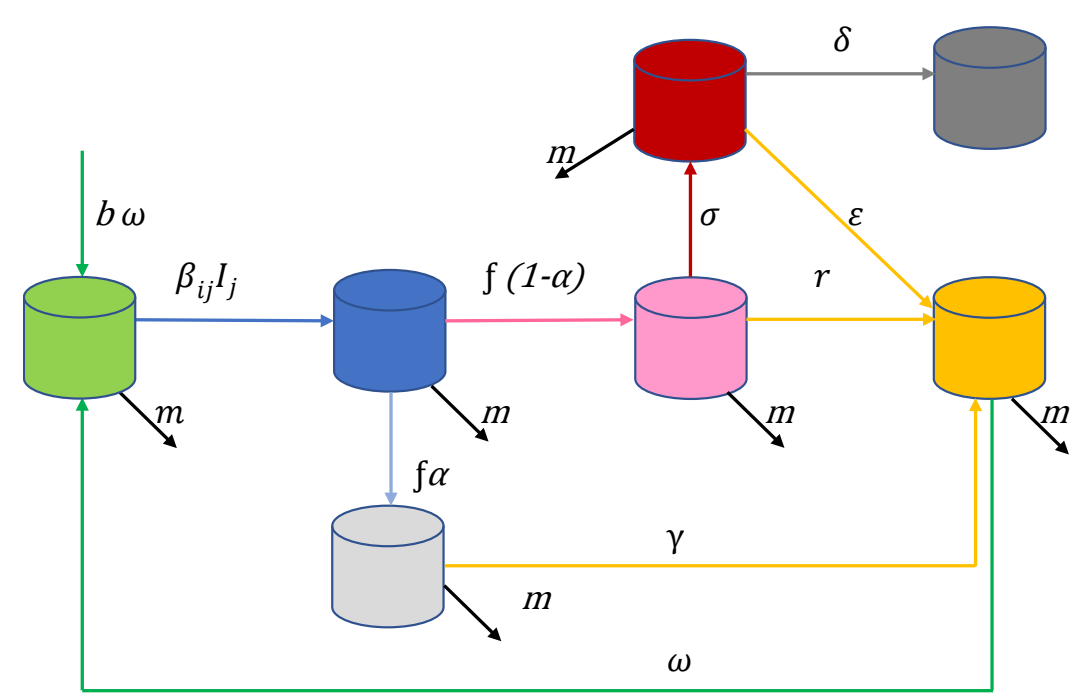

$$
\begin{aligned}
\frac{d S_{i}(t)}{d t} & =b N(t)-\sum_{j=1}^{n} \beta_{i j} I_{j}(t) S_{i}(t)-\sum_{j=1}^{n} \beta_{i j} \eta A_{j}(t) S_{i}(t)+\omega R_{i}(t)-m S_{i}(t) \\
\frac{d E_{i}(t)}{d t} & =\sum_{j=1}^{n} \beta_{i j} I_{j}(t) S_{i}(t)+\sum_{j=1}^{n} \beta_{i j} \eta A_{j}(t) S_{i}(t)-(m+f) E_{i}(t) \\
\frac{d A_{i}(t)}{d t} & =f \alpha E_{i}(t)-(\gamma+m) A_{i}(t) \\
\frac{d I_{i}(t)}{d t} & =f(1-\alpha) E_{i}(t)-\sum_{j=1}^{n} \sigma_{i j} I_{j}(t)-(r+m) I_{i}(t) \\
\frac{d H_{i}(t)}{d t} & =\sum_{j=1}^{n} \sigma_{i j} I_{j}(t)-\sum_{j=1}^{n} \delta_{i j} H_{i}(t)-(\varepsilon+m) H_{i}(t) \\
\frac{d R_{i}(t)}{d t} & =\sum_{j=1}^{n} r_{i j} I_{j}(t)+\sum_{j=1}^{n} \gamma_{i j} A_{j}(t)+\varepsilon H_{i}(t)-(m+\omega) R_{i}(t) \\
\frac{d D_{i}(t)}{d t} & =\sum_{j=1}^{n} \delta_{i j} I_{i}(t)
\end{aligned}
$$

Fig. 1. SEAIHRDS model with demography

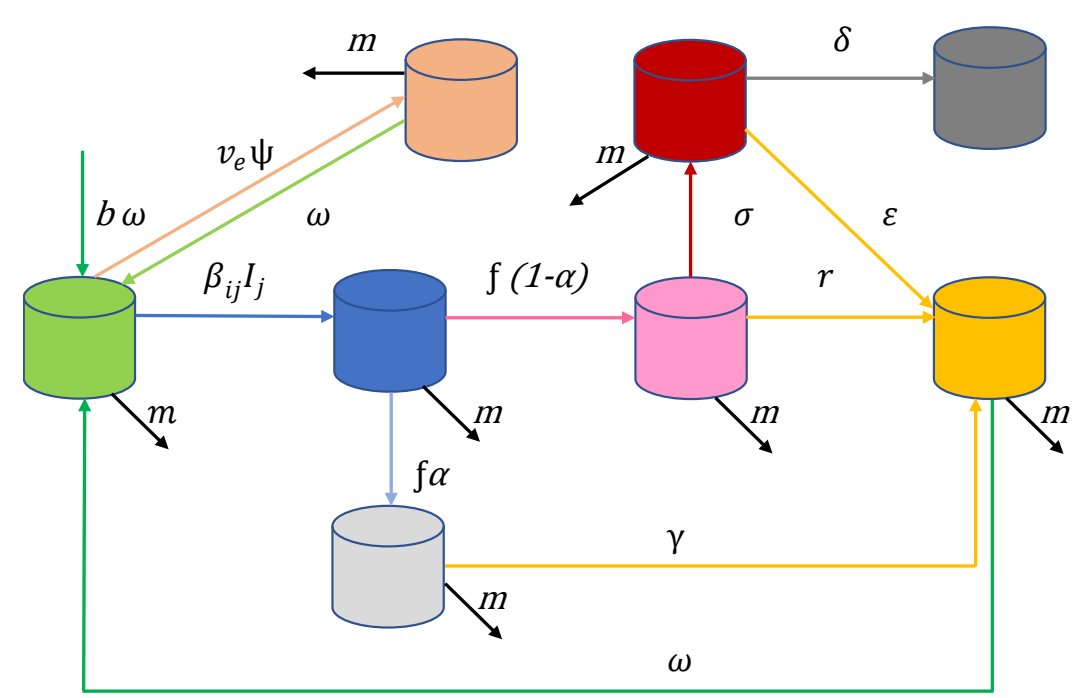

$\frac{d S_{i}(t)}{d t}=b N(t)-\sum_{j=1}^{n} \beta_{i j} I_{j}(t) S_{i}(t)-\sum_{j=1}^{n} \beta_{i j} \eta A_{j}(t) S_{i}(t)+\omega R_{i}(t)-m S_{i}(t)$

$\frac{d E_{i}(t)}{d t}=\sum_{j=1}^{n} \beta_{i j} I_{j}(t) S_{i}(t)+\sum_{j=1}^{n} \beta_{i j} \eta A_{j}(t) S_{i}(t)-(m+f) E_{i}(t)$

$\frac{d A_{i}(t)}{d t}=\mathbf{f} \alpha E_{i}(t)-(\gamma+m) A_{i}(t)$

$\frac{d I_{i}(t)}{d t}=f(1-\alpha) E_{i}(t)-\sum_{j=1}^{n} \sigma_{i j} I_{j}(t)-(r+m) I_{i}(t)$

$\frac{d H_{i}(t)}{d t}=\sum_{j=1}^{n} \sigma_{i j} I_{j}(t)-\sum_{j=1}^{n} \delta_{i j} H_{i}(t)-(\varepsilon+m) H_{i}(t)$

$\frac{d R_{i}(t)}{d t}=\sum_{j=1}^{n} r_{i j} I_{j}(t)+\sum_{j=1}^{n} \gamma_{i j} A_{j}(t)+\varepsilon H_{i}(t)-(m+\omega) R_{i}(t)$

$\frac{d D_{i}(t)}{d t}=\sum_{j=1}^{n} \delta_{i j} I_{i}(t)$

$\frac{d V_{i}(t)}{d t}=v_{e} \psi S_{i}(t)-m V_{i}-\omega V_{i}$.

Fig. 2. SEAIHRDVS model with demography and vaccination 
medRxiv preprint doi: https://doi.org/10.1101/2020.10.21.20216986; this version posted March 4, 2021. The copyright holder for this preprint (which was not certified by peer review) is the author/funder, who has granted medRxiv a license to display the preprint in perpetuity.

It is made available under a CC-BY-NC-ND 4.0 International license .

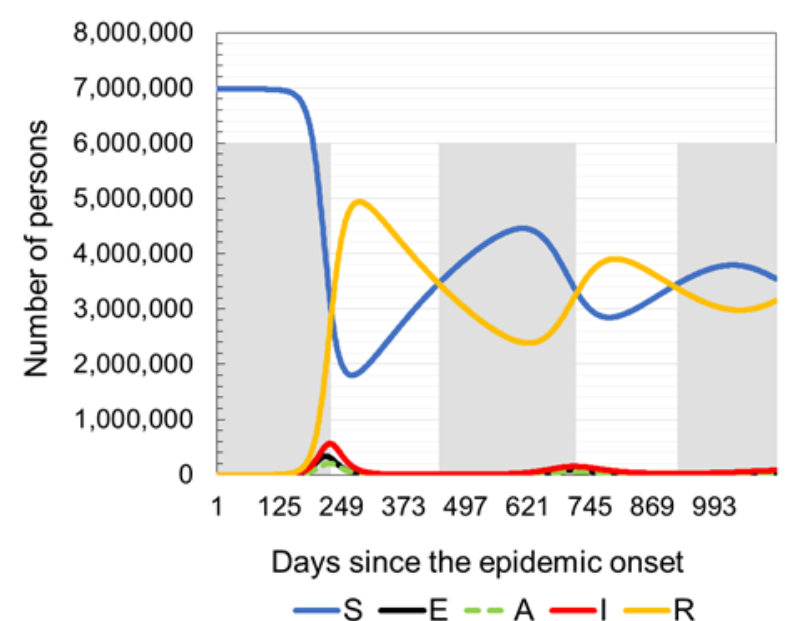

a) Prediction of the total number of the susceptible, latently infected, asymptomatic infectious individuals, infected and recovered on a daily basis since the epidemic onset. No intervention measures applied $\left(\mathrm{R}_{0}=2.46\right)$

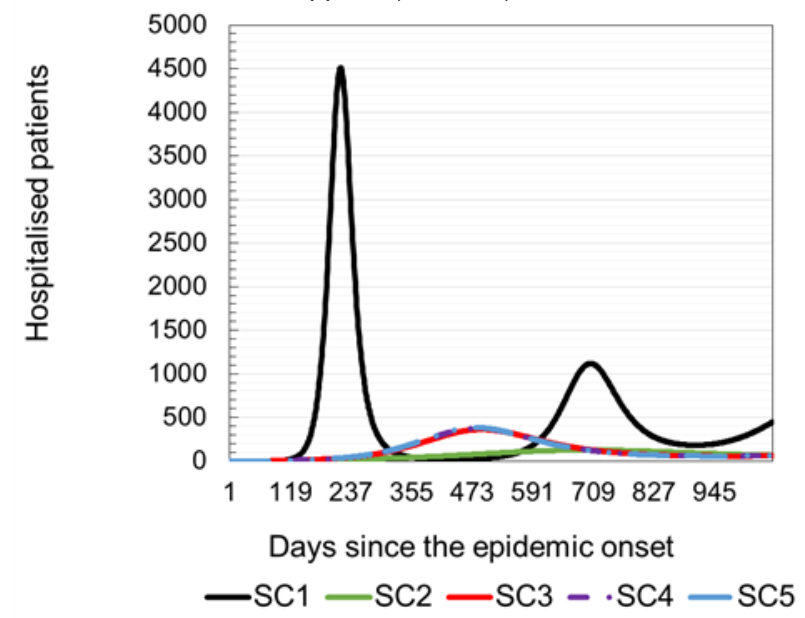

c) The results obtained during the simulation of the application of various contact reduction measures (scenarios $1-5, R_{0}=2.46$ )

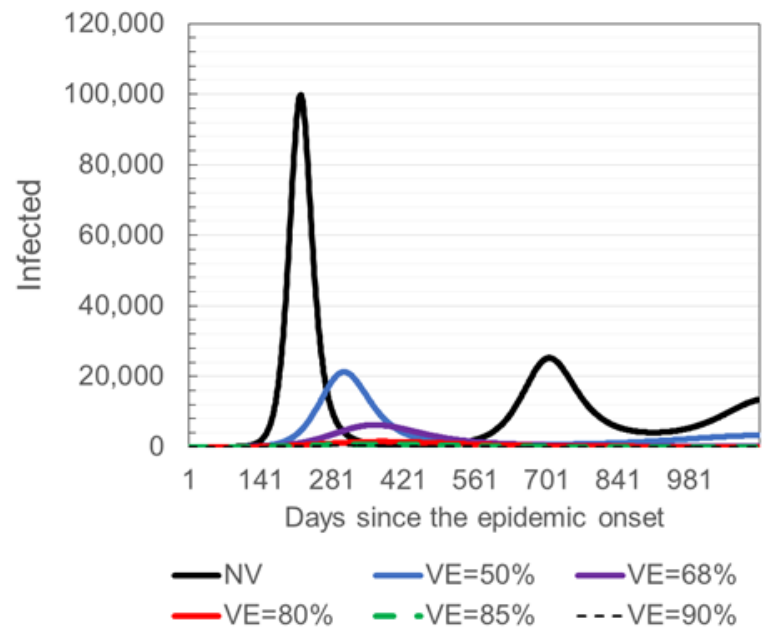

e) Results of simulated COVID19 control based solely on vaccination, scenarios 6-9 $\left(R_{0}=2.46\right)$.

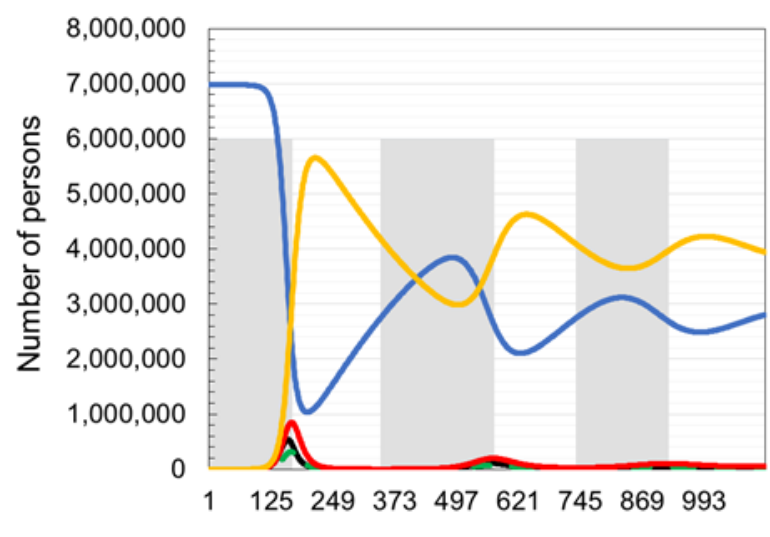

Days since the epidemic onset

$-S-E-A-I-R$

b) Prediction of the total number of the susceptible, latently infected, asymptomatic infectious individuals, infected and recovered on a daily basis since the epidemic onset. No intervention measures applied $\left(R_{0}=3.1\right)$

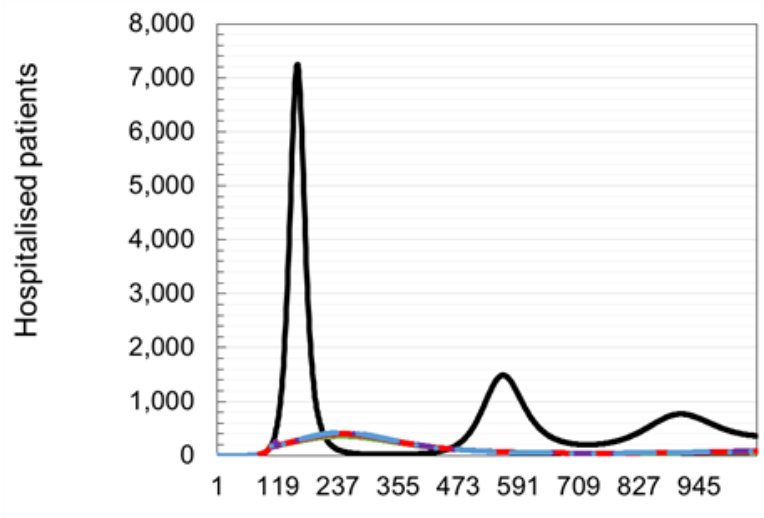

Days since the epidemic onset

- SC1 - SC2 - SC3 - .SC4 - SC5

d) The results obtained during the simulation of the application of various contact reduction measures (scenarios 1-5, $R_{0}=3.1$ )

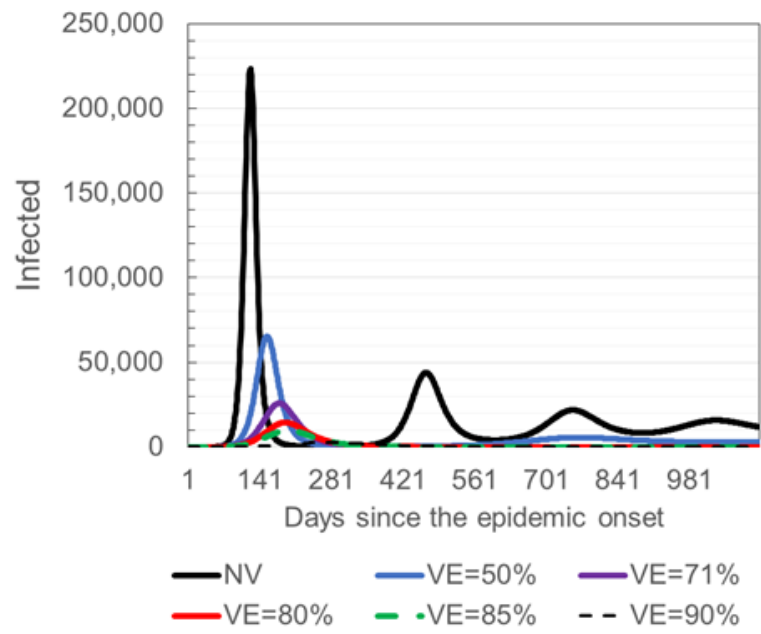

f) Results of simulated COVID19 control based solely on vaccination, scenarios 6-9 $\left(R_{0}=3.1\right)$. 